\title{
Precipitation Characteristics in the Northeast Brazil Dry Region
}

\author{
By \\ Rodolpho Paes Leme Ramos \\ Department of Atmospheric Science \\ Colorado State University \\ Fort Collins, Colorado
}

This report has been partially supported by the National Science Foundation Grant

Numbers GA-32589x2 and GA-29147.

Research Advisor: William M. Gray

*R.P.L. Ramos was under scholarship of the "Fundação de Amparo à Pesquisa do Estado de São Paulo-Brasil".

May 1974
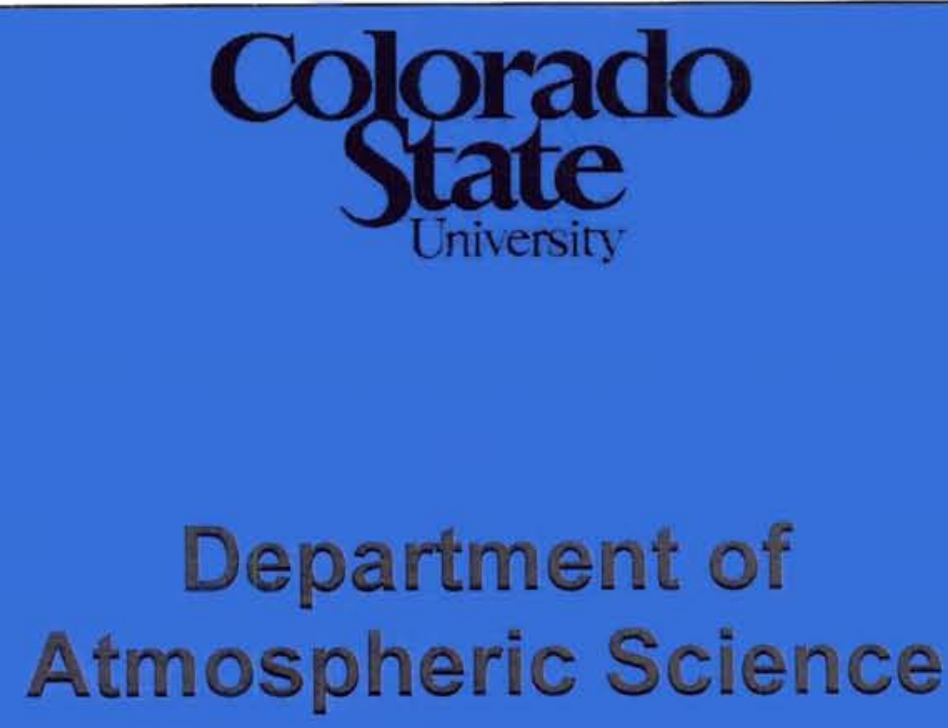

Paper No. 224 
PRECIPITATION CHARACTERISTICS IN THE

NORTHEAST BRAZIL DRY REGION

\author{
by \\ Rodolpho Paes Leme Ramos \\ (under scholarship of the "Fundação de Amparo à Pesquisa \\ do Estado de São Paulo-Brasil")
}

This report has been partially supported

by the National Science Foundation

Grant Numbers GA-32589x2 and GA-29147

Department of Atmospheric Science

Colorado State University

Fort Collins, Colorado

May 1974

Atmospheric Science Paper No. 224 
FOREWORD

Due to growing population pressures and frequent serious drought conditions, it is crucially important that we learn as much as possible about the meteorology and rainfal1 characteristics in the Northeast Brazil dry zone. The recent expansion of the Brazilian tropical upperair network and the growing availability of U.S. satellite data offers the possibility of new meteorological studies which were not possible just a few years ago.

This study represents an attempt to come to grips with the meteorological conditions associated with the Northeast region individual precipitation patterns. New information is offered. It is hoped that this paper will stimulate more thought and research on the meteorology of this region. Many more research opportunities are now available.

The manuscript represents the research portion of Rodolpho P.L. Ramos' Atmospheric Science Master Thesis. I believe this paper makes a significant contribution to the understanding of the precipitation in this region. Since coming to Colorado State University in September, 1972 Rodolpho Ramos has worked very diligently on this research topic. His visit to the U.S. has been supported by the Brazilian government. The financial requirements of this research have been supplied by the U.S. National Science Foundation.

William M. Gray Department of Atmospheric Science Colorado State University 


\begin{abstract}
This paper presents information on the individual episode precipitation characteristics in the Northeast Brazil dry region during its rainy season from December through April. The distribution of rainfall and its frequency are studied in relation to wind, temperature, humidity and pressure fields. It is found that most of the yearly rainfall comes in 6-8 episodes from organized weather systems which move from the east to west with about the same speed $\left(\sim 5 \mathrm{~m} \mathrm{sec}^{-1}\right)$ as the lower tropospheric wind flow. These systems appear not to be of local origin. The ocean is their moisture source. Rainfall is inversely correlated with the regional subsidence and trade wind inversion intensity.

An interesting and previously unknown diurnal rainfall variation has been found. Orographic influences act to modulate the weather systems and develop up-and-downslope winds. This produces rainfa11 in the morning over the lowland regions and in afternoon over the hills and more elevated regions. Other characteristics are discussed.
\end{abstract}


FOREWORD . . . . . . . . . . . . . . . . . . . i i

ABSTRACT . . . . . . . . . . . . . . . . . . $i i$

1. INTRODUCTION . . . . . . . . . . . . . . . . 1

1.1 General . . . . . . . . . . . . . . . . 1

1.2 Climatological Rainfall and Geographic Aspects. . . . . 3

1.3 Objectives. . . . . . . . . . . . . . . . 3

2. DATA SOURCE. . . . . . . . . . . . . . . . . 7

3. PROCESSING OF THE DATA . . . . . . . . . . . . . . 9

3.1 Rainfall Distribution . . . . . . . . . . . 9

3.2 Diurnal Rainfall Distribution . . . . . . . . 15

3.3 Temperature and Water Content . . . . . . . . . . 17

3.4 Pressure and Winds. . . . . . . . . . . . . . 23

3.5 Satellite Pictures. . . . . . . . . . . . 32

3.6 Cloud Cover................. 39

4. DISCUSSION OF RESULTS. . . . . . . . . . . . . . . 45

5. SUMMARY AND CONCLUSIONS. . . . . . . . . . . . . 52

ACKNOWLEDGMENTS. . . . . . . . . . . . . . . . . 54

REFERENCES . . . . . . . . . . . . . . . . . . 55 


\section{INTRODUCTION}

\subsection{General}

The region under consideration is Northeast Brazil between $1^{\circ}$ and $18^{\circ}$ south latitude and between $35^{\circ}$ and $47^{\circ}$ west longitude. This covers

an area of almost 1.6 million $\mathrm{km}^{2}$ (see Fig. 1). This region exhibits a pronounced time and space variability in the rainfall distribution, with a drastic dry inland region where the annual normal rainfall is below 500 millimeters ( $\sim 20$ inches). Serious social and economic problems result from the regional population requirements of over 20 million people and their dependence upon agriculture. It is noteworthy that the region is located in a latitudinal band where a regular distribution of rainfall should be expected. This region was first settled in the early 16 th century. It is felt that in previous centuries the rainfall was somewhat greater than it is now. Some natural or man induced climate changes may have taken place. It is difficult to forecast the weather in this area due to the lack of detailed knowledge of the tropospheric wind structure and its influence on meteorological phenomena. Careful investigation of the relationship between wind, temperature, moisture and weather distribution, as we11 as the orographic influences, would provide a better understanding of the rainfall amounts and their variability. This should increase the reliability of weather forecasts required to carry out the many meteorologically sensitive human activities in this region. This is the purpose of this study. 


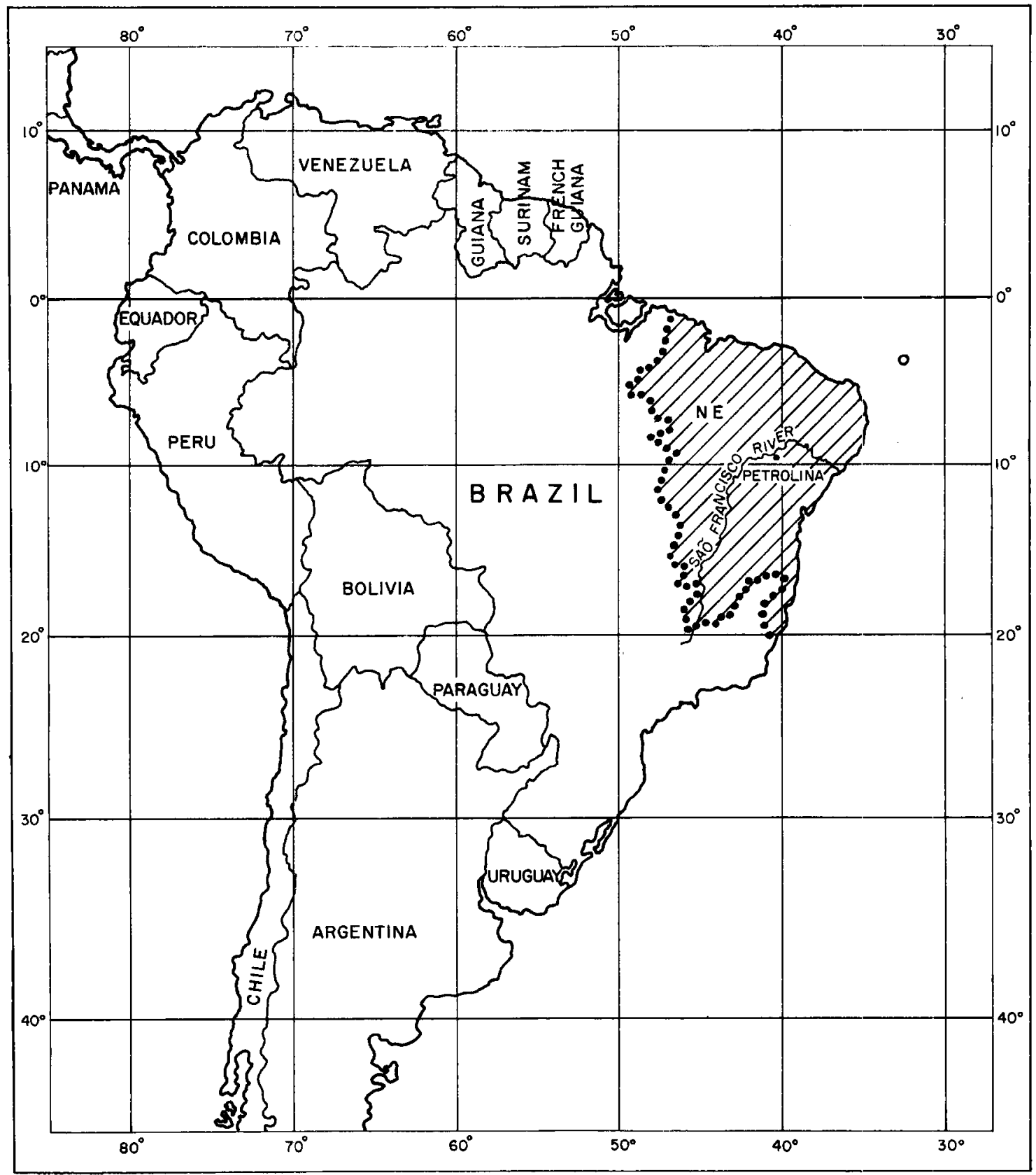

Fig. 1. South America - shadow area shows the Northeast Brazil (NE). 


\subsection{Climatological Rainfal1 and Geographic Aspects}

Figure 2 shows the mean annual isohyets for the period 1931-1960 as computed by Strang (1972). The isohyet of 1200 millimeters ( 50 inches) closely follows the dry region. This "dry polygon" covers an area of about 0.94 million $\mathrm{km}^{2}$. The regions with precip:.tation above this limit are considered to have adequate moisture for agriculture. Precipitation amounts below this amount are not adequate in total amount or in reliability. Minimum rainfall occurs in the central part of the states of Paraiba and Pernambuco, as well as near the city of Petrolina in the São Francisco Valley, where the average annual rainfall is below 500 millimeters ( $\sim 20$ inches). A comprehensive climatological analysis of rainfall normals in Northeast Brazil was made by Strang in 1972 . Additional information on the climatology of this region is supplied by reports of "Diretoria de Rotas Aêreas--Brasil" (1967, 1968), "Escritório de Meteorologia--Brasil" (1970), Hoschele (1970), Aldaz (1971), Brophy and Piva (1971), "Departamento Naciona1 de Meteorologia--Brasi1" (1972b) and by maps of "Departamento Nacional de obras contra as Secas-Brasi1" (1965).

Figure 3 shows the orography of the region. The main orographic influence to the rainfall near Petrolina is the hills (or elevated terrain) to the west. The base of these hills (or elevated terrain) is about 40 kilometers away. They have an average altitude of 700 meters, and the highest part is 900 meters above sea level. The altitude of the Petrolina region is about 370 meters.

\subsection{Objectives}

The primary objective of this paper is the investigation of the characteristics of the precipitation of Northeast Brazil in the Petrolina 


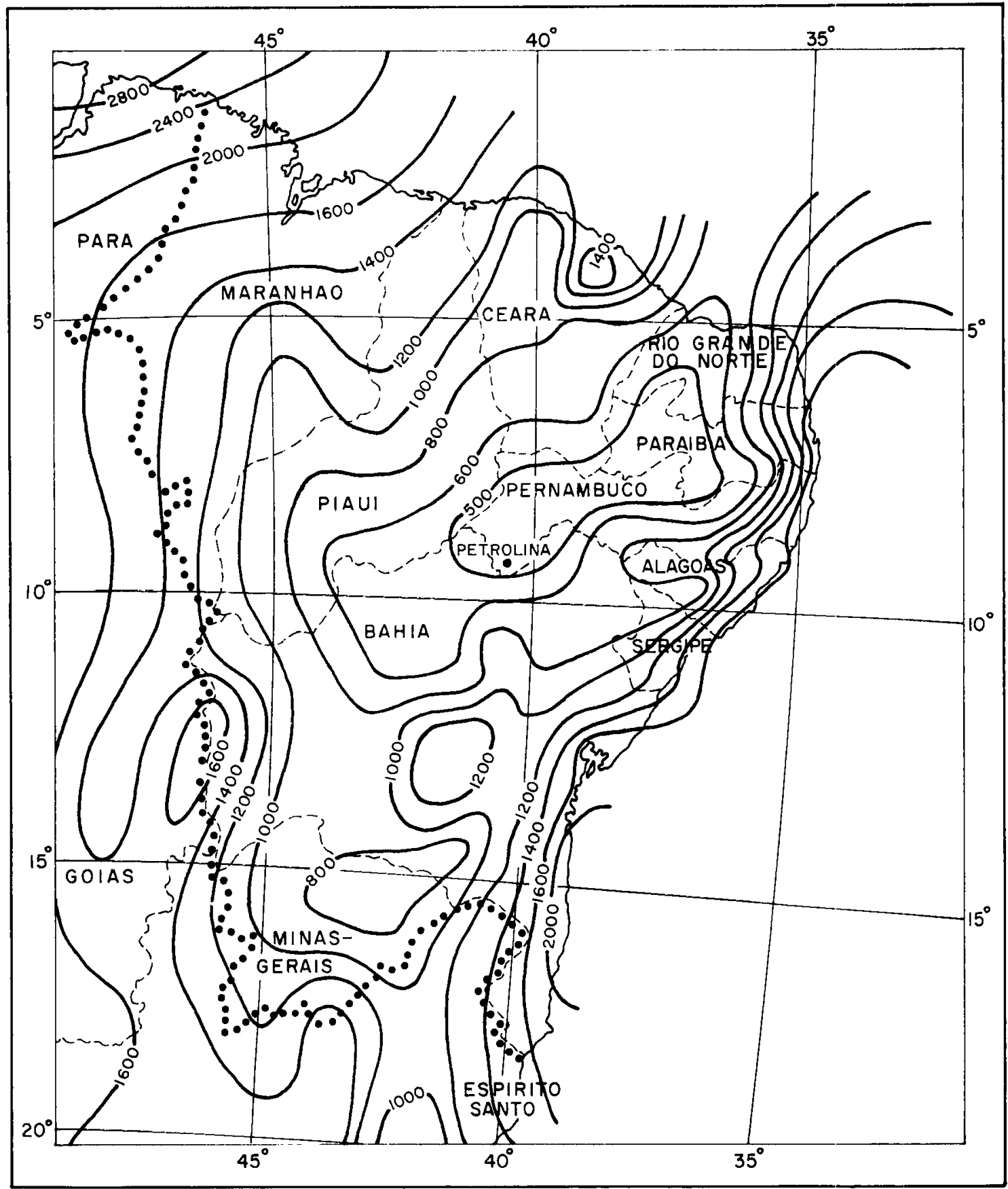

Fig. 2. Mean annual isohyets for the period 1931-1960, given in millimeters, as computed by Strang (1972). 


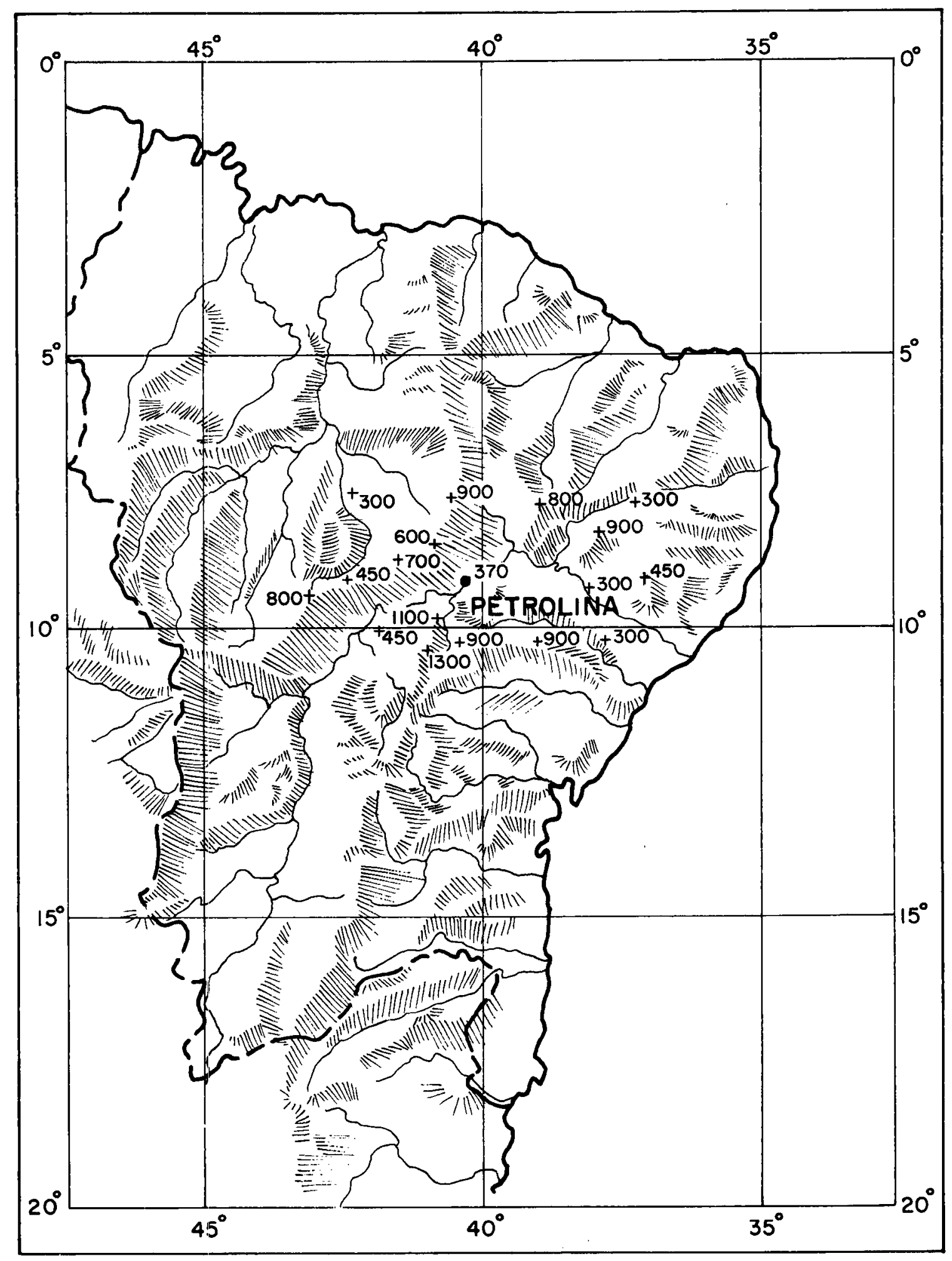

Fig. 3. Orography of Northeast Brazil--numbers inside indicate heights above the sea level in meters. 
area during its rainy season from January to April. Is the rainfall associated with traveling weather systems? How frequent is it? Does it have an orographic character? These and other questions are to be answered. Lack of a sufficient period of record for upper-air observations necessitated using only a single year, 1972, with its complete reporting network. This is the only year of upper-air information available to the author. Petrolina is located in the Northeast dry region and has a very reliable radiosonde station. The precipitation data indicates that the rainfall patterns of this year are typical of most other years, however. Although there is great variability of the annual rainfall in this region, this study shows that this variability is due to an over abundance or a lack of a few traveling meso-scale rain systems. This study cannot treat the year to year variations of precipitation but rather will discuss the inter-year variability. Background material on this research is partially supplied by Conrad and Pellak (1950); Rieh1 (1954); Smithsonian Meteorological Tables (1966); Lorenz (1967); Rotas Aéreas--Brasil" (1969); Atkinson (1971); "Serviço de Meteorologia--Brasil" (1971); Namias (1972); "Departamento Nacional de Meteorologia--Brasil" (1972a, 1973); Williams and Gray (1973); Gray (1973); Ruprecht and Gray (1974); and Gray, Ruprecht and Phelps (1974). 


\section{DATA SOURCE}

To deal with the Petrolina area in a realistic way, it was necessary that representative information including upper winds, vapor contents, temperature, rainfal1, cloud covers, etc., be obtained for Northeast Brazil. To accomplish this, the author performed extensive analysis of the radiosonde, pilot balloon, surface, satellite, and rainfall data.

Figure 4 shows the meteorological network of Northeast Brazil from which data were used to carry out this investigation.* Besides this network there are many other places where rainfall data are recorded and which were used in this study.

The data were collected, organized and mailed by the Division of Meteorology of the "Instituto de Atividades Espaciais" of the "Centro Técnico Aeroespacial" of the Brazilian Air Force.

Besides this we also borrowed from NESS the ATS-3 movie loops.

*The data received from Brazil in microfilms were:

a) Radiosonde observations--once every day (08-09LT);

b) Pilot Balloon observations--once every day (08-09LT);

c) Surface observations--24 or 14 every day (hourly);

d) Rainfall measurements--daily records and local time of occurrence;

e) Surface analysis--four every day (00, 06, 12 and 18Z);

f) Upper-air streamlines analysis for $850,700,500,400,300,250$ and $200 \mathrm{mb}$--once every day (12Z);

g) Satellite pictures from ESSA 8--once every day--(morning time); 


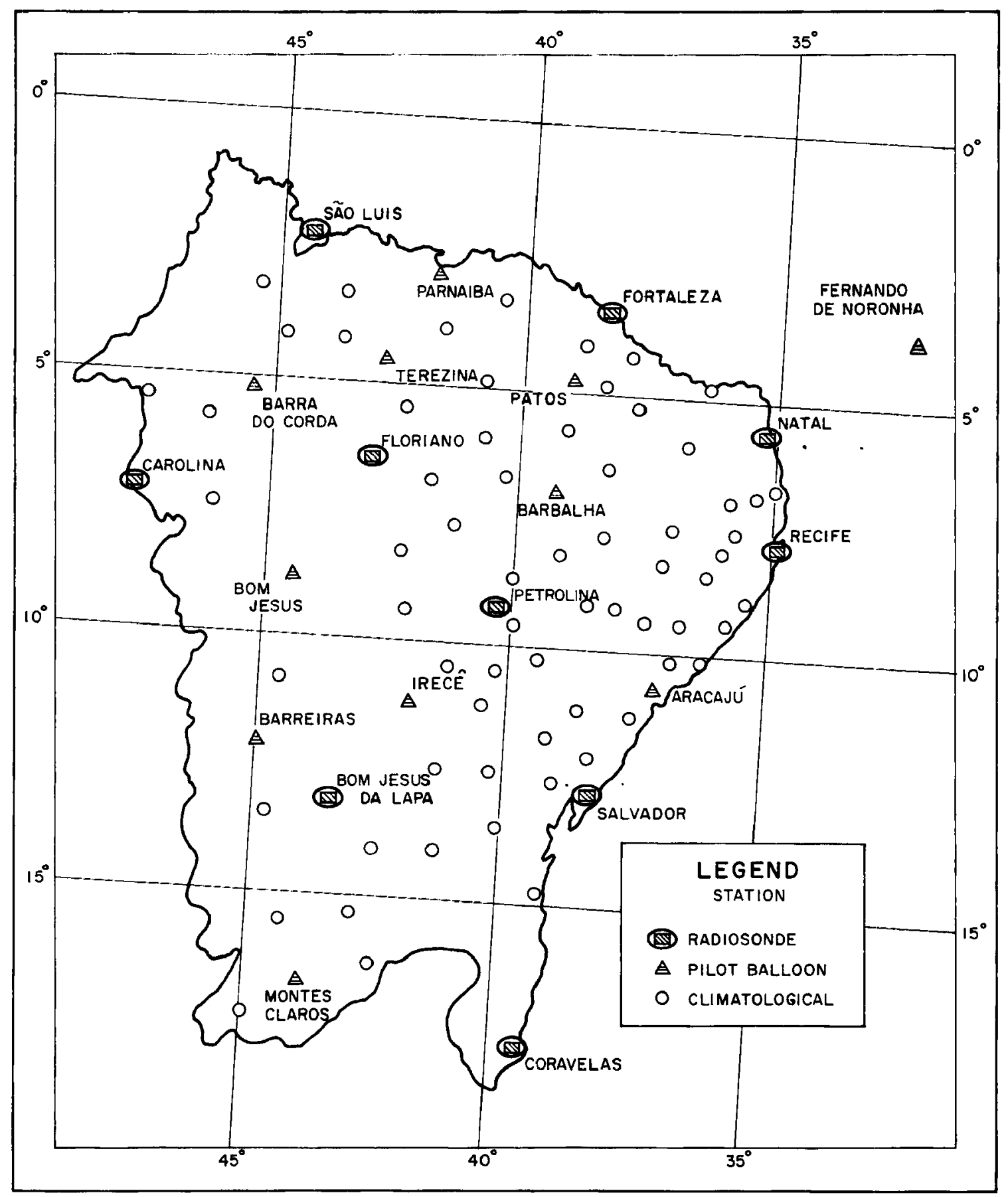

Fig. 4. Meteorological network of Northeast Brazil. 


\section{PROCESSING OF THE DATA}

\subsection{Rainfa11 Distribution}

During 1972 Petrolina had 43 rain days but only 13 days with precipitation of more than $10 \mathrm{~mm}$ ( 0.4 inches) per day. The rainiest month in Petrolina was March with $\sim 170 \mathrm{~mm}$, the second month was December with $\sim 110 \mathrm{~mm}$, the third and fourth months were January and February with 80 and $70 \mathrm{~mm}$ of precipitation. Table 1 and Fig. 5 show total and percent frequency of rainfall for 1972 and : 30 years rainfall (1931-1960) normal for comparison. There was a total of eight rainy periods in 1972 and, of the 13 days which had over $10 \mathrm{~mm}$ of percipitation, 10 occurred from January to April in seven individual rainy episodes. Thus, the 1972 rainy season was very similar to the long term average of the rainfall.

Table 1

Rainfall over Petrolina in 1972 and Comparison with 1931-1960 Normal 1972

Norma1 (1931-1960)

\begin{tabular}{|c|c|c|c|c|}
\hline Month & $\begin{array}{l}\text { Total } \\
(\mathrm{mm})\end{array}$ & $\begin{array}{c}\text { Frequency } \\
(\%)\end{array}$ & $\begin{array}{l}\text { Total } \\
(\mathrm{mm})\end{array}$ & $\begin{array}{c}\text { Frequency } \\
(\%)\end{array}$ \\
\hline January & 79 & 15 & 48 & 10 \\
\hline February & 70 & 13 & 85 & 18 \\
\hline March & 171 & 33 & 95 & 20 \\
\hline April & 60 & 12 & 40 & 8 \\
\hline May & 3 & 1 & 27 & 6 \\
\hline June & 16 & 3 & 15 & 3 \\
\hline July & 2 & 0 & 8 & 2 \\
\hline August & 2 & 0 & 6 & 1 \\
\hline September & 0 & 0 & 5 & 1 \\
\hline October & 0 & 0 & 8 & 2 \\
\hline November & 9 & 2 & 64 & 14 \\
\hline December & 109 & 21 & 73 & 15 \\
\hline ALL YEAR & 521 & 100 & 474 & 100 \\
\hline
\end{tabular}




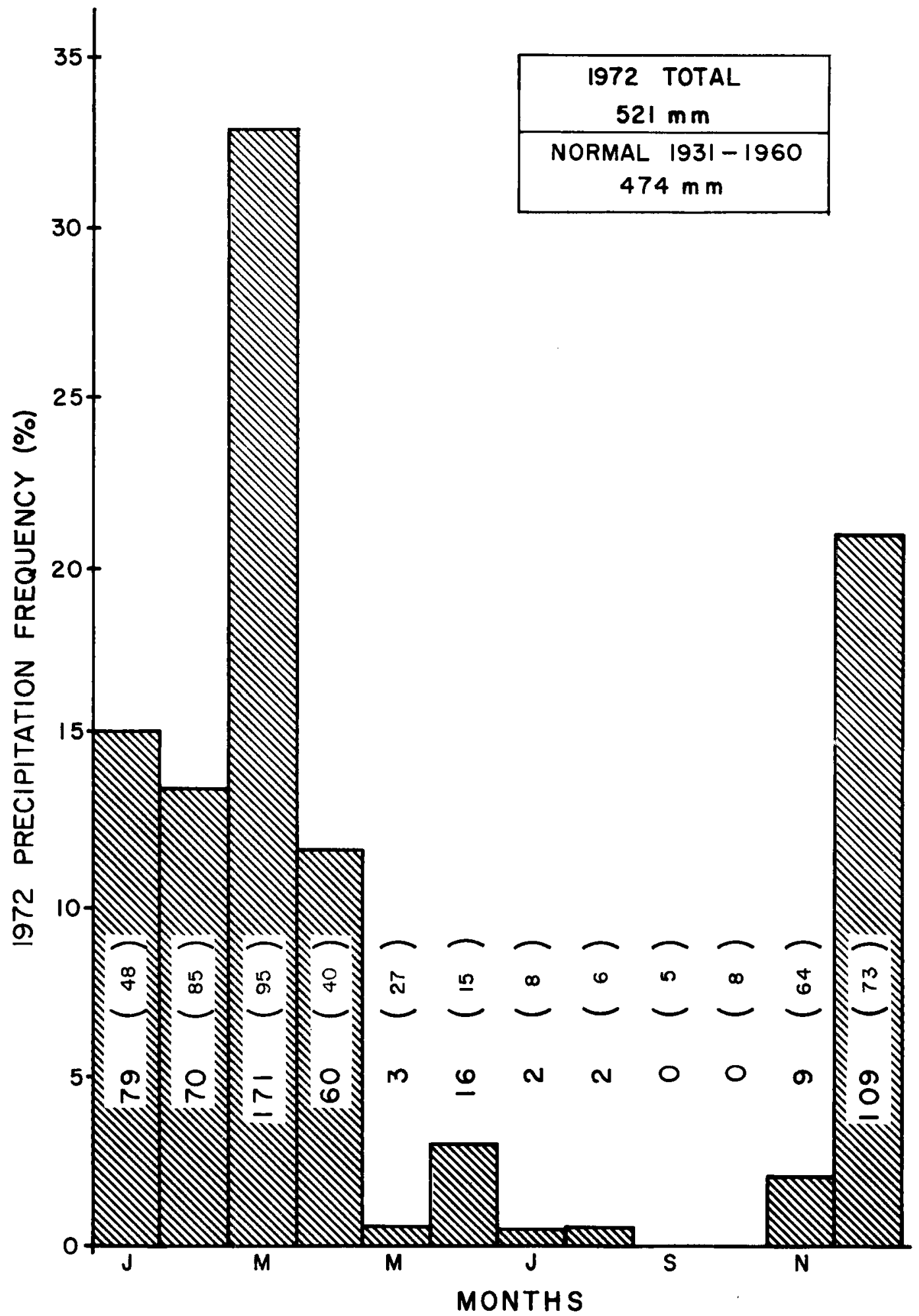

Fig. 5. 1972 monthly rainfall amounts (in millimeters) and monthly percentage frequency for Petrolina (hatched values). Numbers in parenthesis are the monthly 30 years (1931-1960) precipitation normals in millimeters. 
The rainy season pertinent to this investigation occurs from December to April. The seven precipitation episodes occurring from January to April 1972 will be discussed. Of the $521 \mathrm{~mm}$ total rainfall in 1972 almost three-quarters or $2380 \mathrm{~mm}$ fell during the four months of January to Apri1. Nearly all of this or $\sim 377 \mathrm{~mm}$ fell during seven selective rain periods of $2-3$ days duration. This is a little above the normal value of $268 \mathrm{~mm}$ for the 30 years (1931-1960) average of the same four months. The difference between $1972(521 \mathrm{~mm})$ and the 30 year normal annual $(474 \mathrm{~mm})$ is not felt significant. Figure 6 shows the daily rainfall distribution in Petrolina from January to April with its seven selective periods of precipitation. Table 2 shows the amounts of rainfall and time of occurrence for each day in the seven rainy periods. Maximum rainfall fell on the median days which are underlined.

Each rainy period was studied for seven days: The day of maximum rainfall and the three days before (minus) and after (plus). The days of maximum rainfall for each of the seven rainy periods are: January 19, February 13, February 18, March 2, March 19, March 31, and April 12. Precipitation measurements were recorded each day at 09 local time (LT), which means that the rainfall recorded was from 09LT of the previous day until 09LT of the day of the measurement. Figure 7 is a composite of rainfall for these seven rainy periods plotted relative to the day of maximum rainfall. Note how most of the rain is concentrated in the day of maximum precipitation. The one day precipitation is likely to occur in but a few hours. 


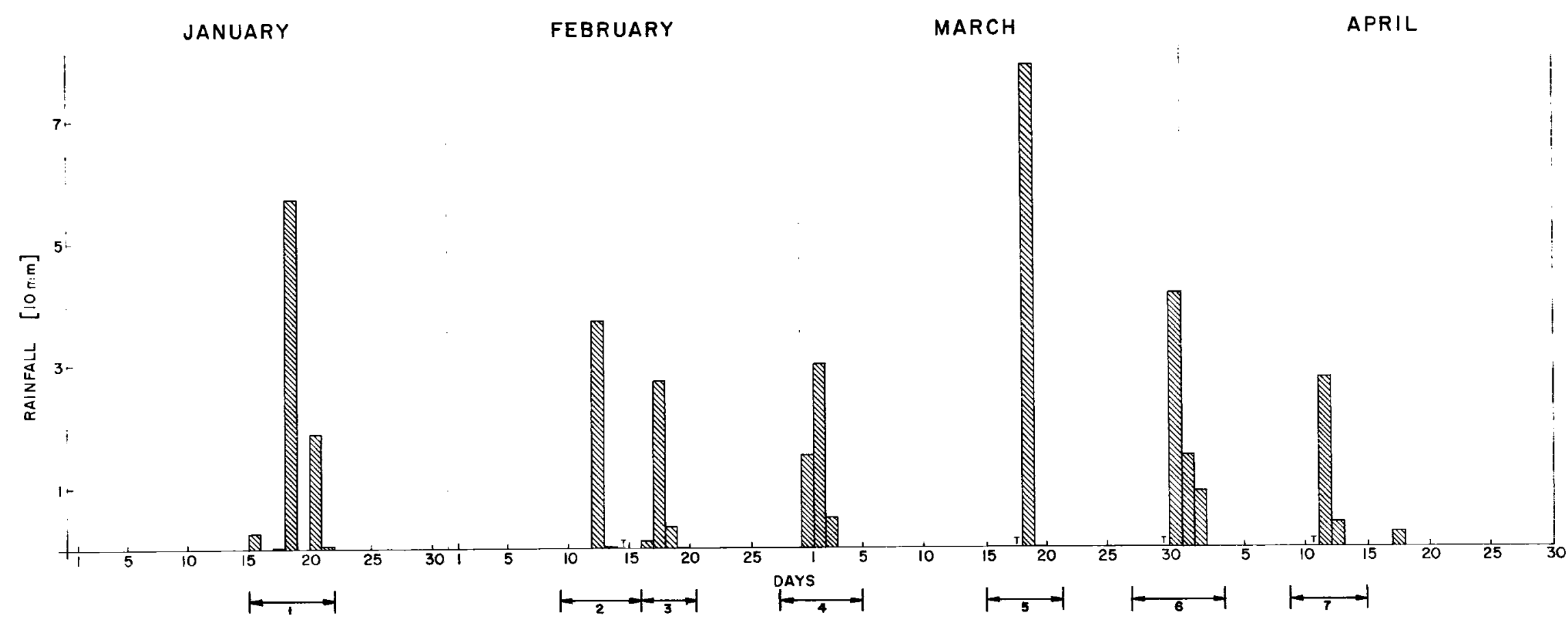

Fig. 6. Rainfall distribution in Petrolina from January to April 1972 and the seven precipitation episodes which will be discussed. 
Table 2

Hourly Rain Occurrence at Petrolina, X Signifies that Rain Occurred During the Hours Indicated

Each rain period was taken to be of 7 days from 3 days before to 3 days after the days of maximum rainfall which is underlined.

Rainfall amounts were recorded each day at 09 local time, which means that the rainfall recorded was from 09 local time of the previous day until 09 local time of the day of the measurement. Presence of rain was determined by the hourly current weather information.

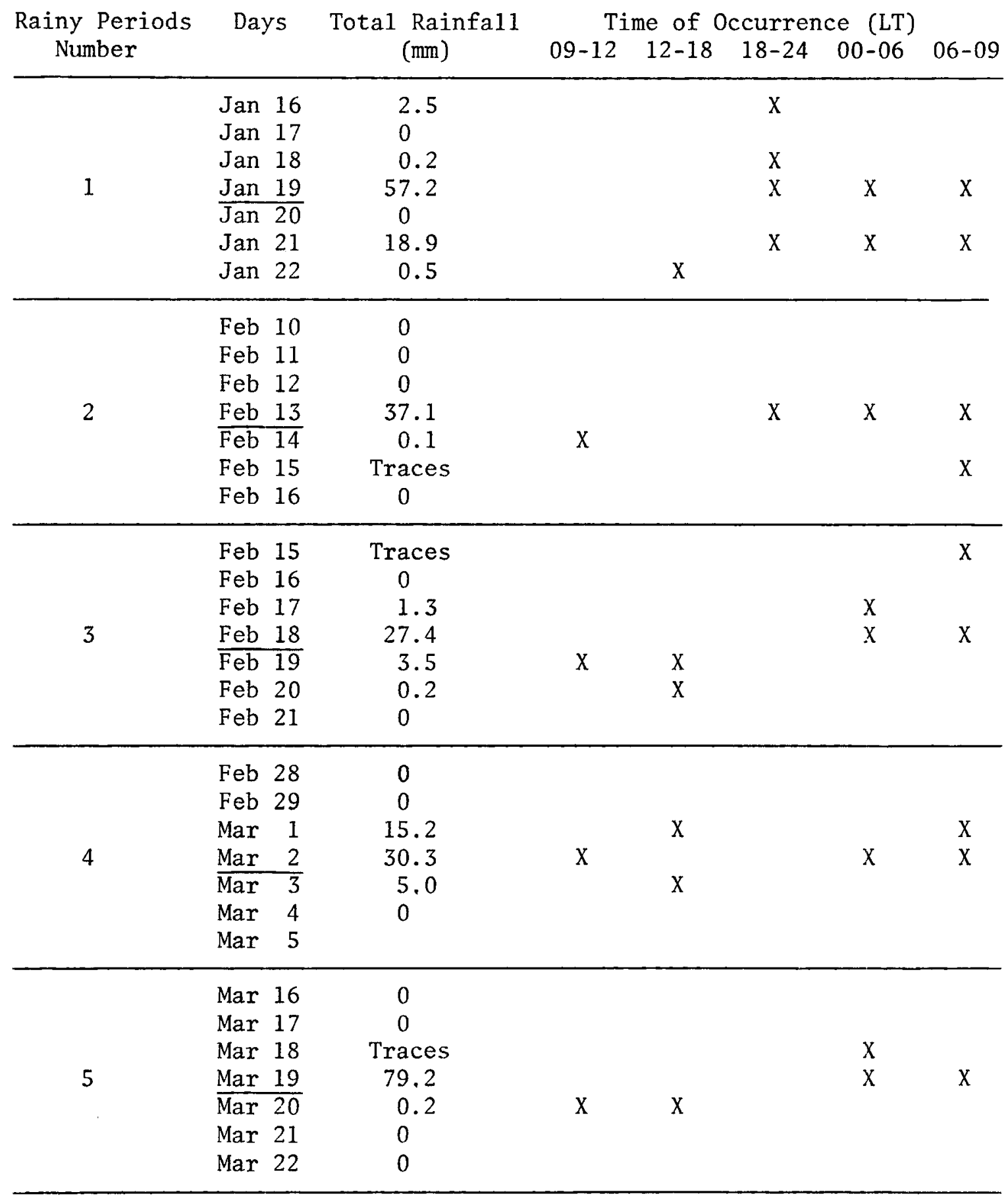


Table 2 (cont'd)

\begin{tabular}{|c|c|c|c|c|c|c|c|}
\hline \multirow{2}{*}{$\begin{array}{l}\text { Rainy Periods } \\
\text { Number }\end{array}$} & \multirow[t]{2}{*}{ Days } & \multirow{2}{*}{$\begin{array}{c}\text { Total Rainfall } \\
(\mathrm{mm})\end{array}$} & \multicolumn{5}{|c|}{ Time of Occurrence (LT) } \\
\hline & & & $09-12$ & $12-18$ & $18-24$ & $00-06$ & $06-09$ \\
\hline \multirow{7}{*}{6} & Mar 28 & 0 & & & \multirow{7}{*}{$\mathrm{X}$} & \multirow{7}{*}{$\begin{array}{l}X \\
X \\
X\end{array}$} & \\
\hline & $\operatorname{Mar} 29$ & 0 & & & & & \\
\hline & $\operatorname{Mar} 30$ & Traces & & & & & \\
\hline & $\operatorname{Mar} 31$ & 41.5 & & & & & \\
\hline & $\overline{\mathrm{Apr} \quad 1}$ & 15.3 & & & & & \\
\hline & Apr 2 & 9.4 & & & & & \\
\hline & Apr 3 & 0 & & & & & \\
\hline \multirow{7}{*}{7} & Apr 9 & 0 & & & & & \multirow{7}{*}{$\begin{array}{l}\mathrm{X} \\
\mathrm{X}\end{array}$} \\
\hline & Apr 10 & 0 & & & & & \\
\hline & Apr 11 & Traces & & & & & \\
\hline & Apr 12 & 28.0 & & & & & \\
\hline & Apr 13 & 4.4 & $\mathrm{X}$ & & & & \\
\hline & Apr 14 & 0 & & & & & \\
\hline & Apr 15 & 0 & & & & & \\
\hline
\end{tabular}

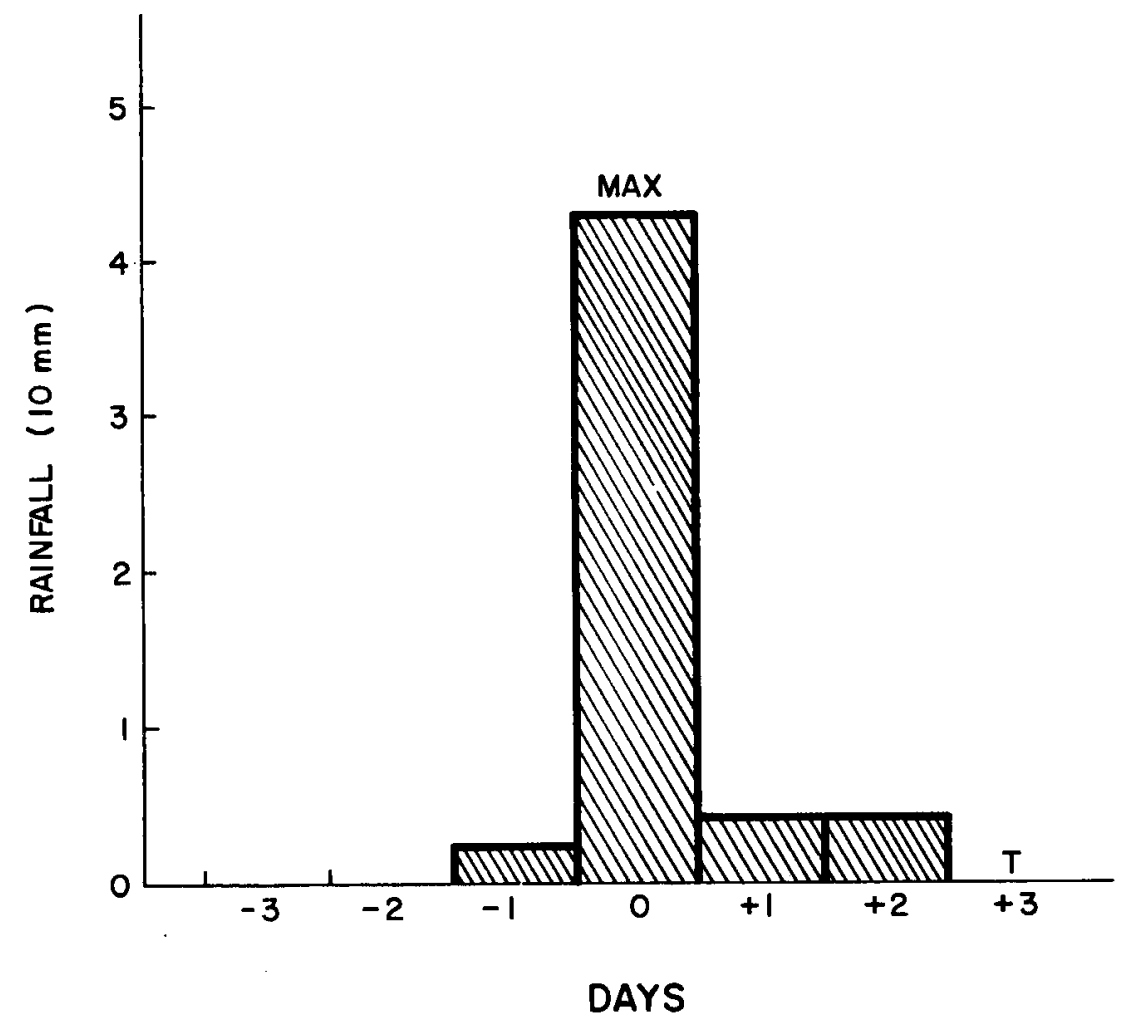

Fig. 7. Rainfall averaged for the seven rain periods from three days before to three days after maximum rainfall at Petrolina. Minus numbers indicate days before and plus numbers mean days after maximum rain day. 


\subsection{Diurnal Rainfall Distribution}

Figure 8 shows the diurnal rainfall frequency during the seven rain periods in Petrolina and for three elevated terrain stations to the west for comparison. Note that the diurnal rainfall distribution for the western hills (or elevated terrain) and for Petrolina is outof-phase. Table 3 also shows the diurnal rainfall occurrences and frequency during the same seven rain episodes for Petrolina region and for the elevated terrain region to the west of Petrolina. It can be seen that for all the 49 days of the seven rainy periods, Petrolina had 57 hourly records of rain occurrence, the elevated terrain stations 49 . Of these 57 Petrolina cases, 44 or $\sim 77$ percent occurred in the morning. of these 44 morning occurrences 228 or two-thirds occurred between the hours of 00-06LT. This was quite unexpected. Over the elevated terrain to the west the daily distribution of rainfall frequency was more regular. Maximum frequency was in the afternoon. Why the rainfall occurs mainly in the morning in Petrolina as opposed to the afternoon when surface temperatures are a maximum and why Petrolina has so few days of rainfall is discussed later.

Figure 9 shows the composite rainfall relative to the center of the seven precipitation regimes as they passed through Northeast Brazil. The center of Fig. 9 coincides with the center of the rain systems and each concentric circle represents the radial distances from the disturbance. The numbers on the left side of Fig. 9 represent the rainfall average of all precipitation which fell three days before to three days after the maximum rain day at Petrolina. Thus (7 episodes) x ( 7 time periods) or 49 time periods are included in the average. 


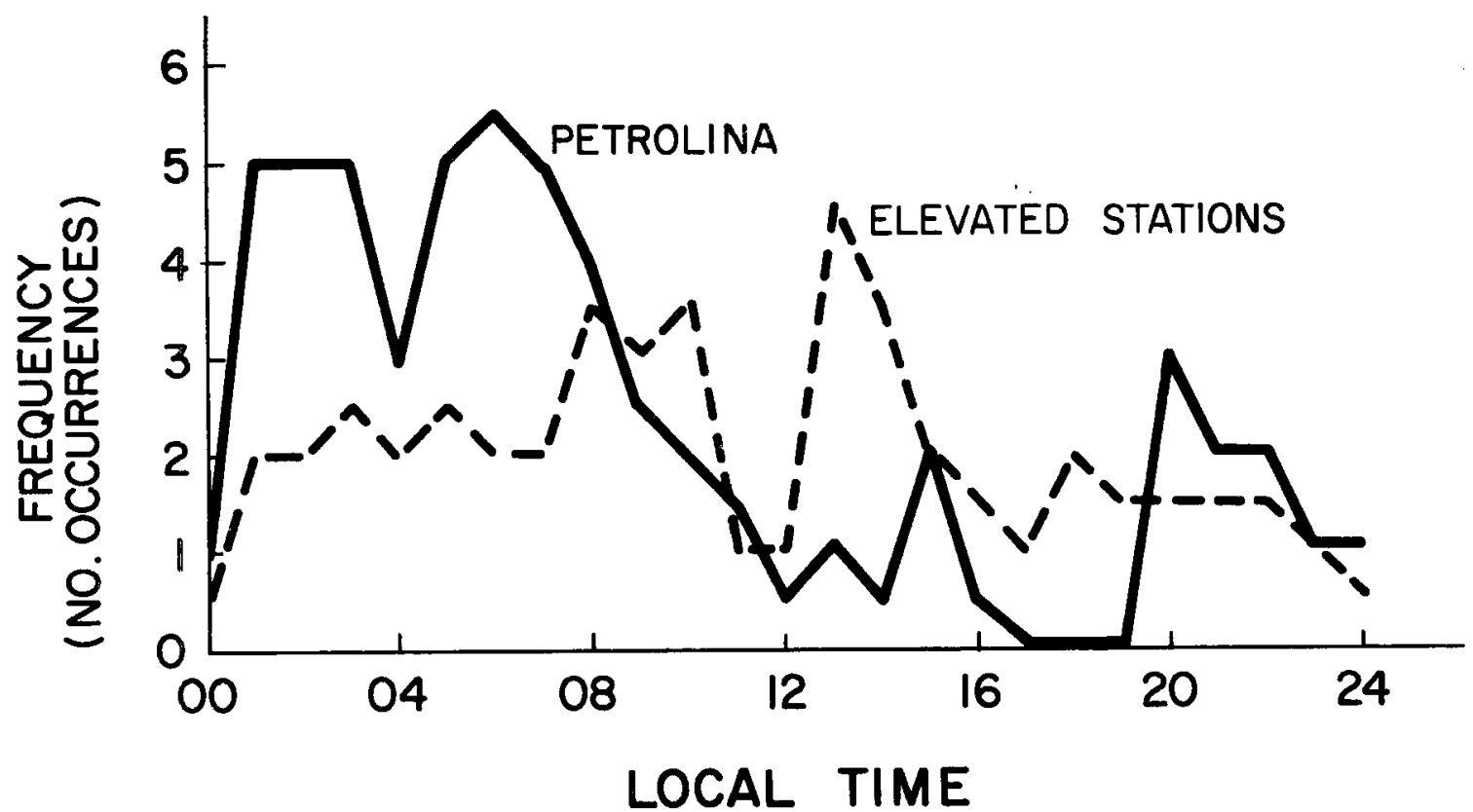

Fig. 8. Diurnal rainfall frequency for the seven rain periods. Averaged data from Petrolina region (solid curve) and averaged data from three elevated terrain stations to the west of Petrolina (dashed curve).

Table 3

Rainfall Occurrences During the Seven Rain Episodes at Petrolina

Pt - Averaged data from Petrolina region

Et - Averaged data from three elevated terrain stations to the west of Petrolina

Time Occurrence

No. Occurrences

Frequency $(\%)$

\begin{tabular}{lcccc}
\hline Local Time (LT) & Pt & Et & Pt & Et \\
\hline $\begin{array}{l}\text { Early Morning } \\
\text { (after 00 to 06) }\end{array}$ & 28 & 13 & 49 & 27 \\
\hline $\begin{array}{l}\text { Late Morning } \\
\text { (after 06 to 12) }\end{array}$ & 16 & 14 & 28 & 29 \\
\hline $\begin{array}{l}\text { Afternoon } \\
\text { (after 12 to 18) }\end{array}$ & 4 & 15 & 7 & 30 \\
\hline $\begin{array}{l}\text { Evening } \\
\text { (after 18 to 24) }\end{array}$ & 9 & 7 & 16 & 14 \\
\hline TOTAL & 57 & 49 & 100 & 100
\end{tabular}




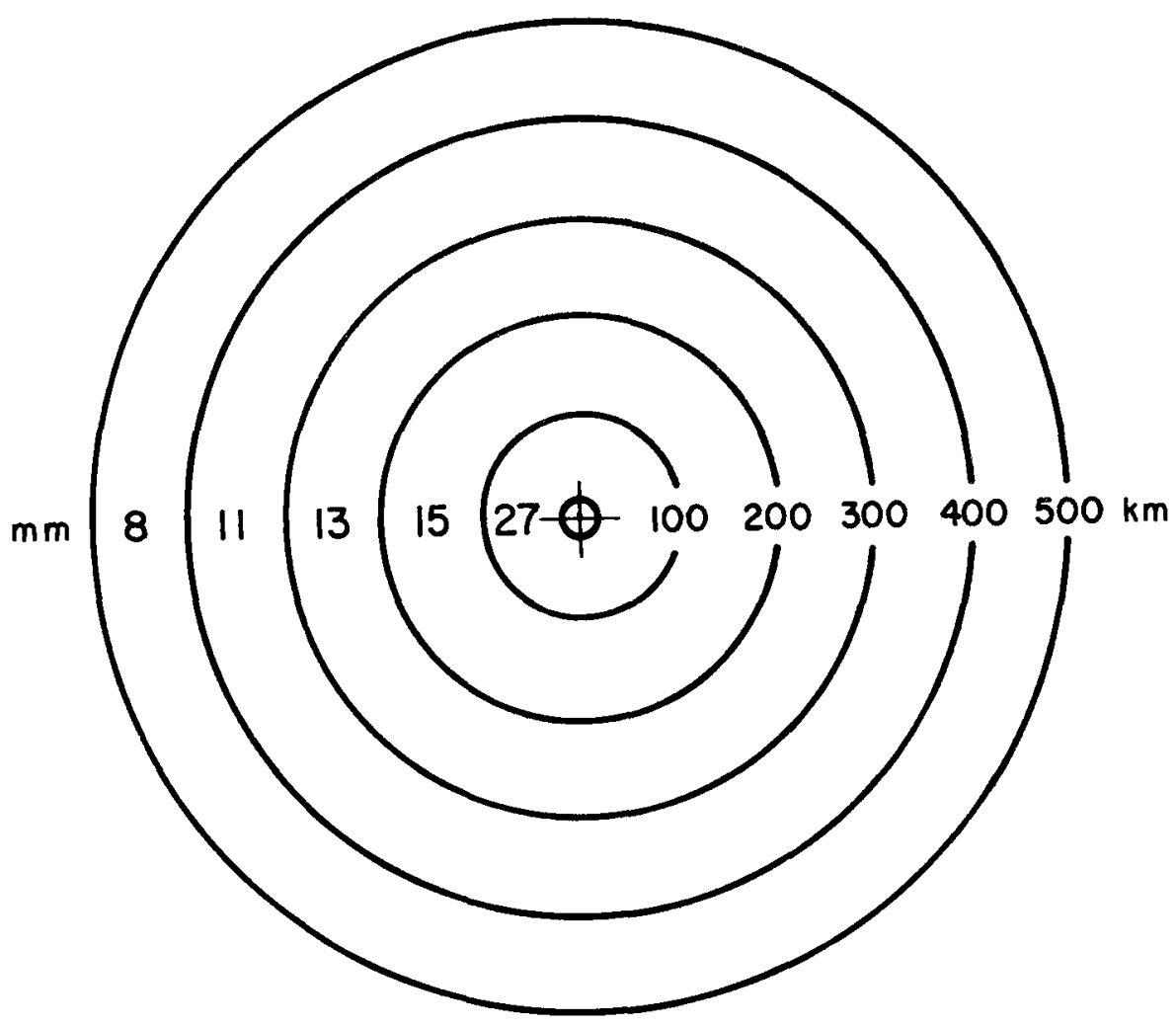

Fig. 9. Area distribution of averaged daily rainfall in millimeters relative to the center of the seven traveling precipitation systems. Mean rainfall (left side), and distance from the weather system center (right side).

\subsection{Temperature and Water Content}

Figures $10 \mathrm{a}$ to $10 \mathrm{~g}$ portray the seven period averaged daily soundings relative to the day of maximum precipitation at Petrolina. Seven SKEW T, LOG P diagrams are shown for the average temperature (right curve) and average dew point (left curve) for the separate seven periods of three days before to three days after maximum precipitation at Petrolina. Values of the precipitable water in $\mathrm{g} \mathrm{cm}^{-2}$ for every $100 \mathrm{mb}$ layer are shown on the left side of these figures. Amounts were graphically computed from the formula:

$$
M=\int_{P_{1}}^{P_{2}} q \frac{\delta p}{g}
$$




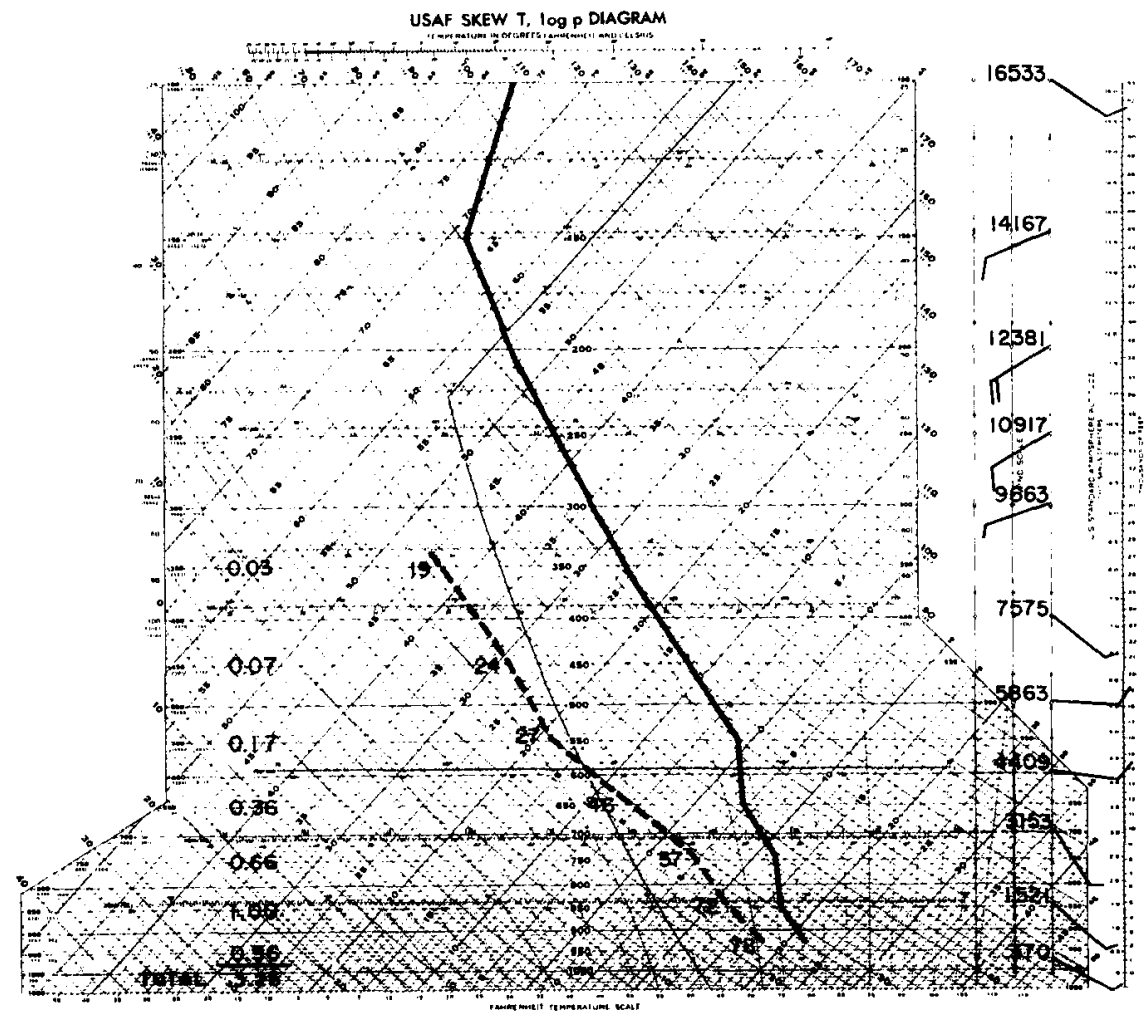

Fig. 10a. Averaged temperature and dew point curves for Petrolina three days before the heaviest rain day for the seven rainy episodes. Relative humidity is shown along the dew point curve (dashed). Mean wind vectors (in knots) are shown on the right as well as the geopotential heights (in meters). 2 On the left side is recorded the precipitable water in $\mathrm{g} \mathrm{cm}^{-2}$ between $100 \mathrm{mb}$ pressure intervals. 


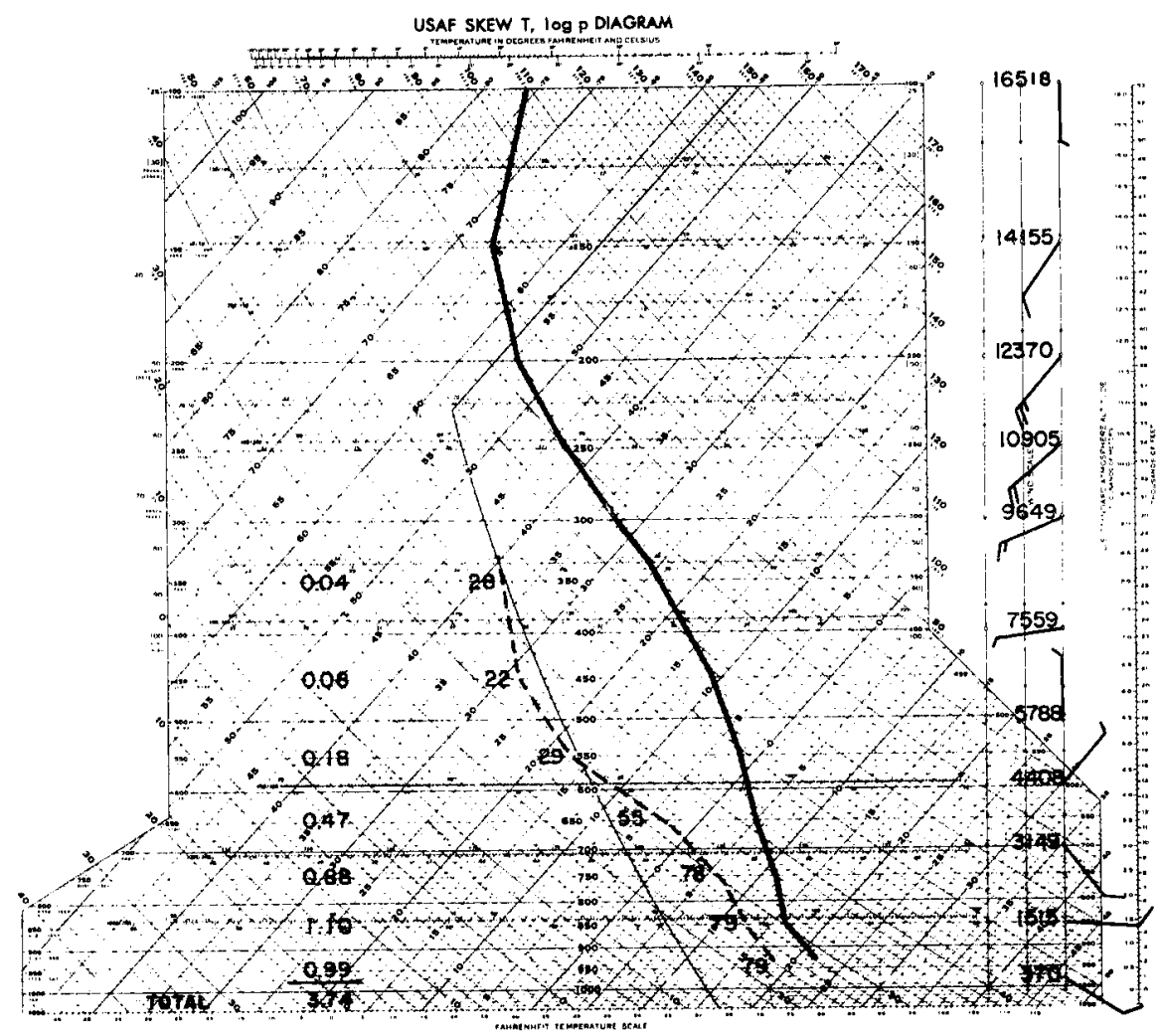

Fig. 10b. Same as for Fig. 10a except for two days before the maximum rain episode.

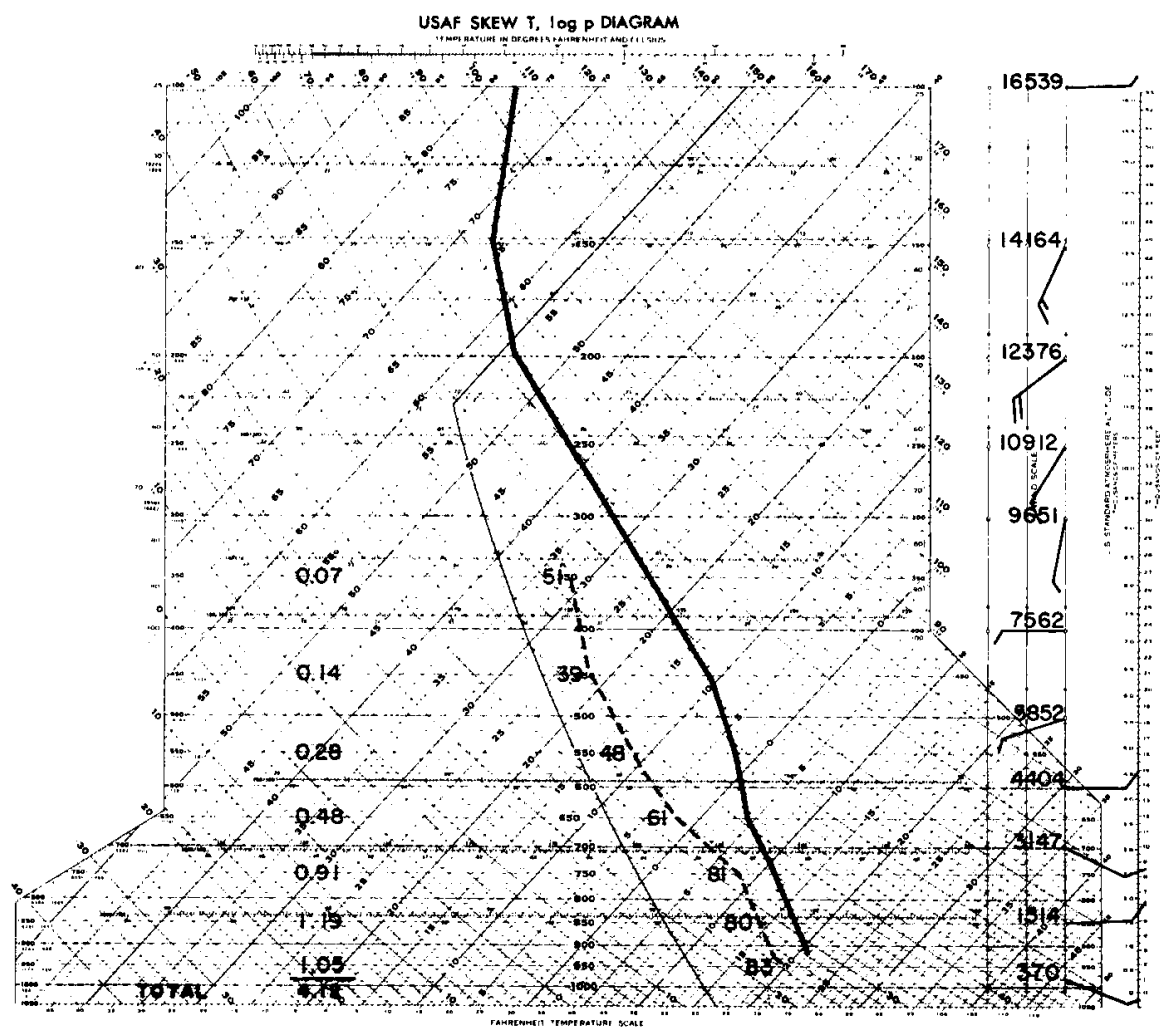

Fig. 10c. Same as for Fig. 10a except for one day before the maximum rain episode. 


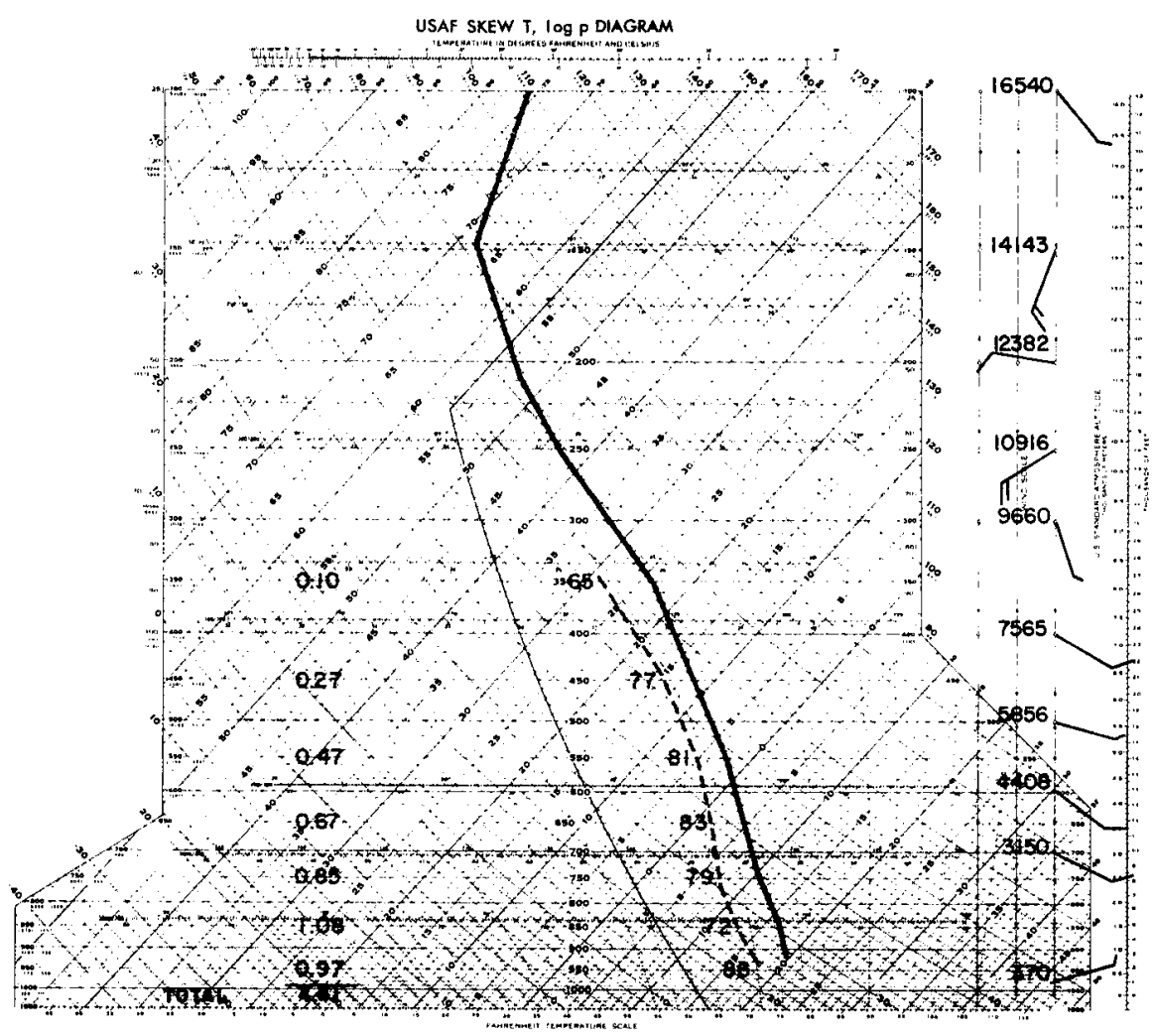

Fig. 10d. Same as for Fig. 10a except for the day of maximum rain episode.

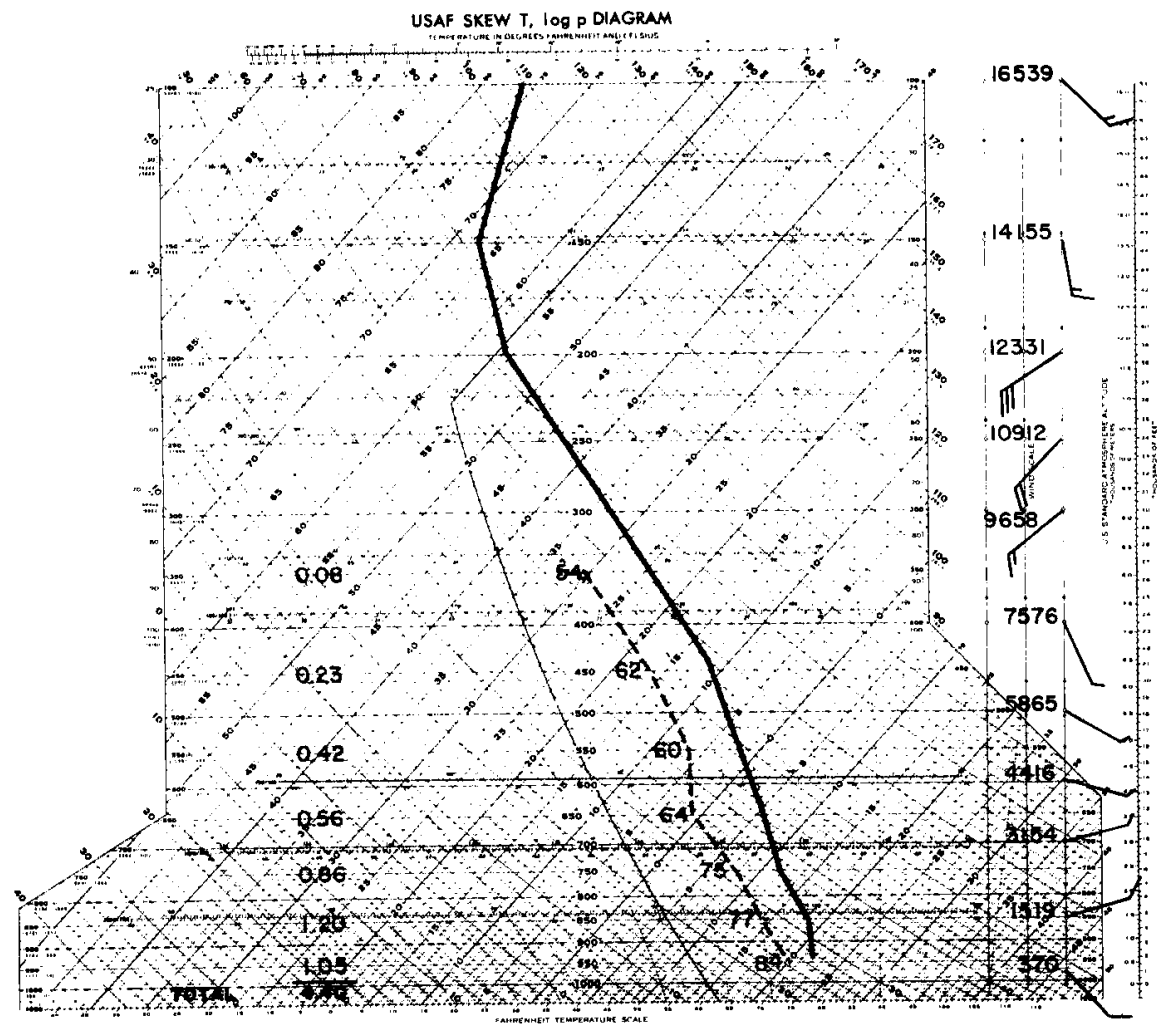

Fig. 10e. Same as for Fig. 10a except for one day after the maximum rain episode. 


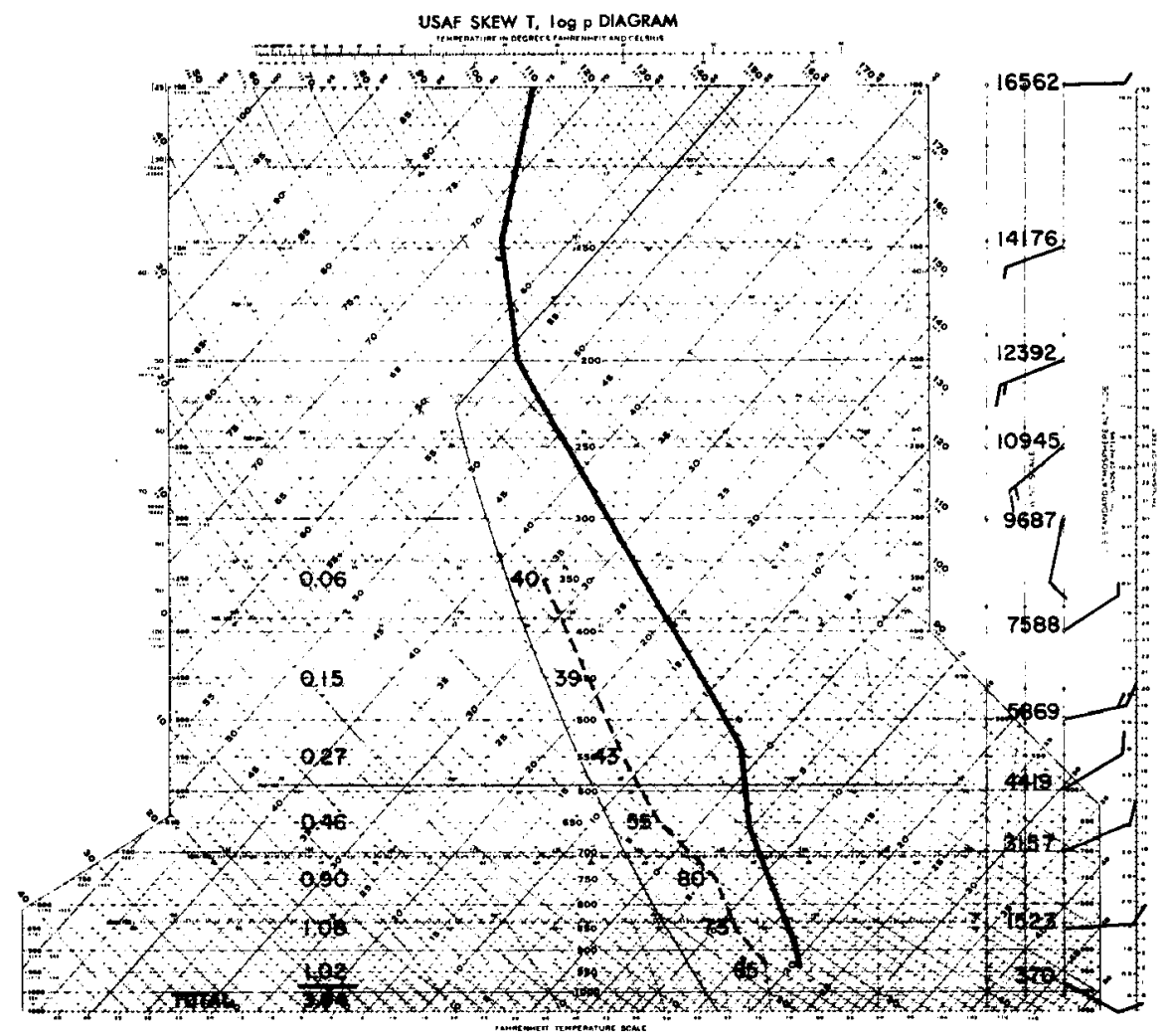

Fig. 10f. Same as for Fig. 10a except for two days after the maximum rain episode.

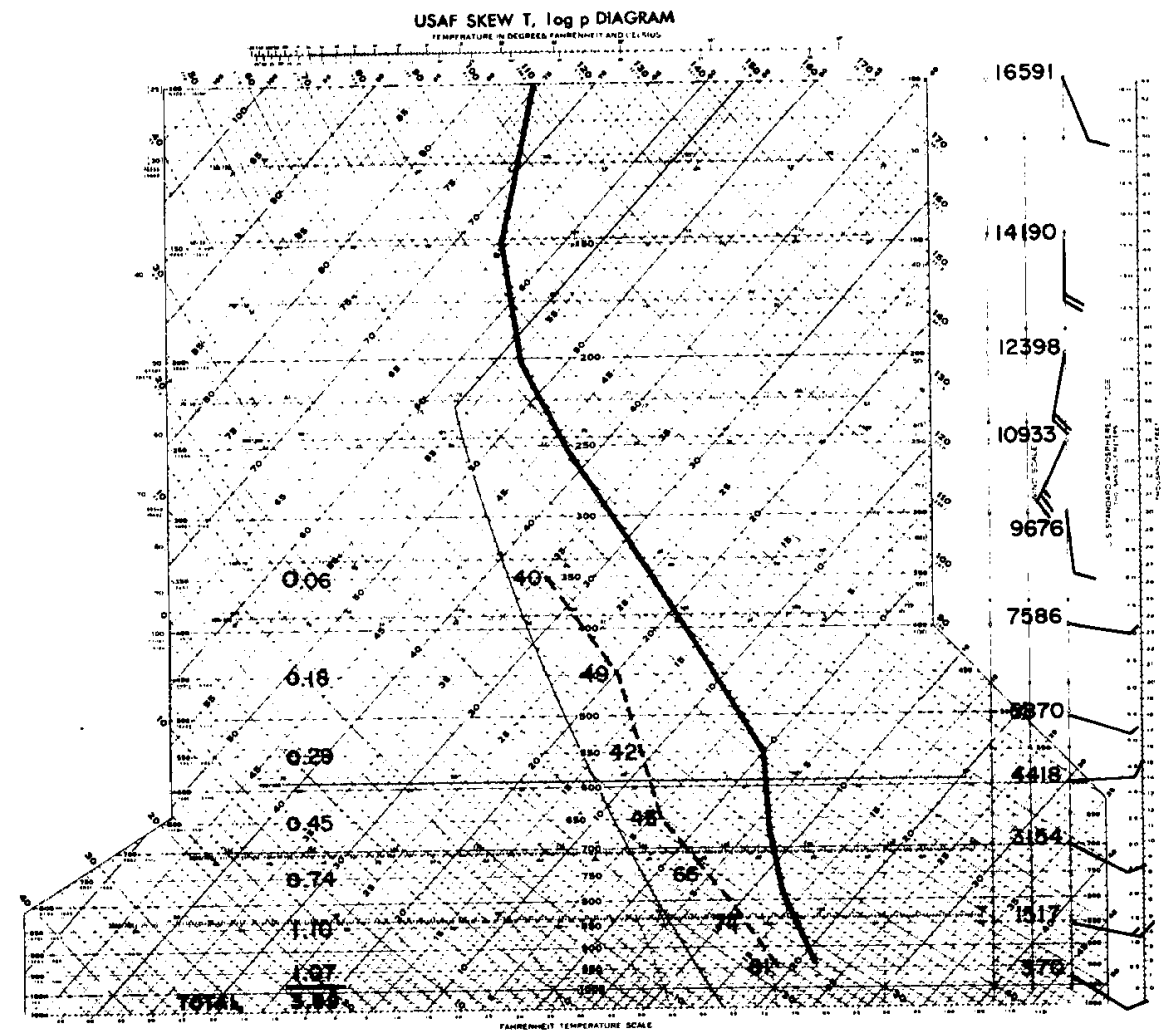

Fig. 10g. Same as for Fig. 10a except for three days after the maximum rain episode. 
where $M$ is the precipitase from $P_{1}$ to $P_{2}$, $\mathrm{q}$ is the specific humidty, and $s$ is gravity. Relative humidity is shown along the dew point crrve. Later Table 4 more explicitly portrays these daily relative hmidity variations as differences from the rainiest day average. The right side of these figures shows the averaged vector winds in standart five knot wind barb units. The geopotential heights in meters are also shown. For comparison Fig. 10h is included which represents the same parameters described but for the averaged seven driest days during the January to April rainy season. The primary difference in those soundings are to be found in the middle level water vapor contents. During rain periods middle level humidity is substantially larger than it is during non-rain periods. By contrast, the temperature, geopotenticl heights, and zonal winds show only small rainy season differences.

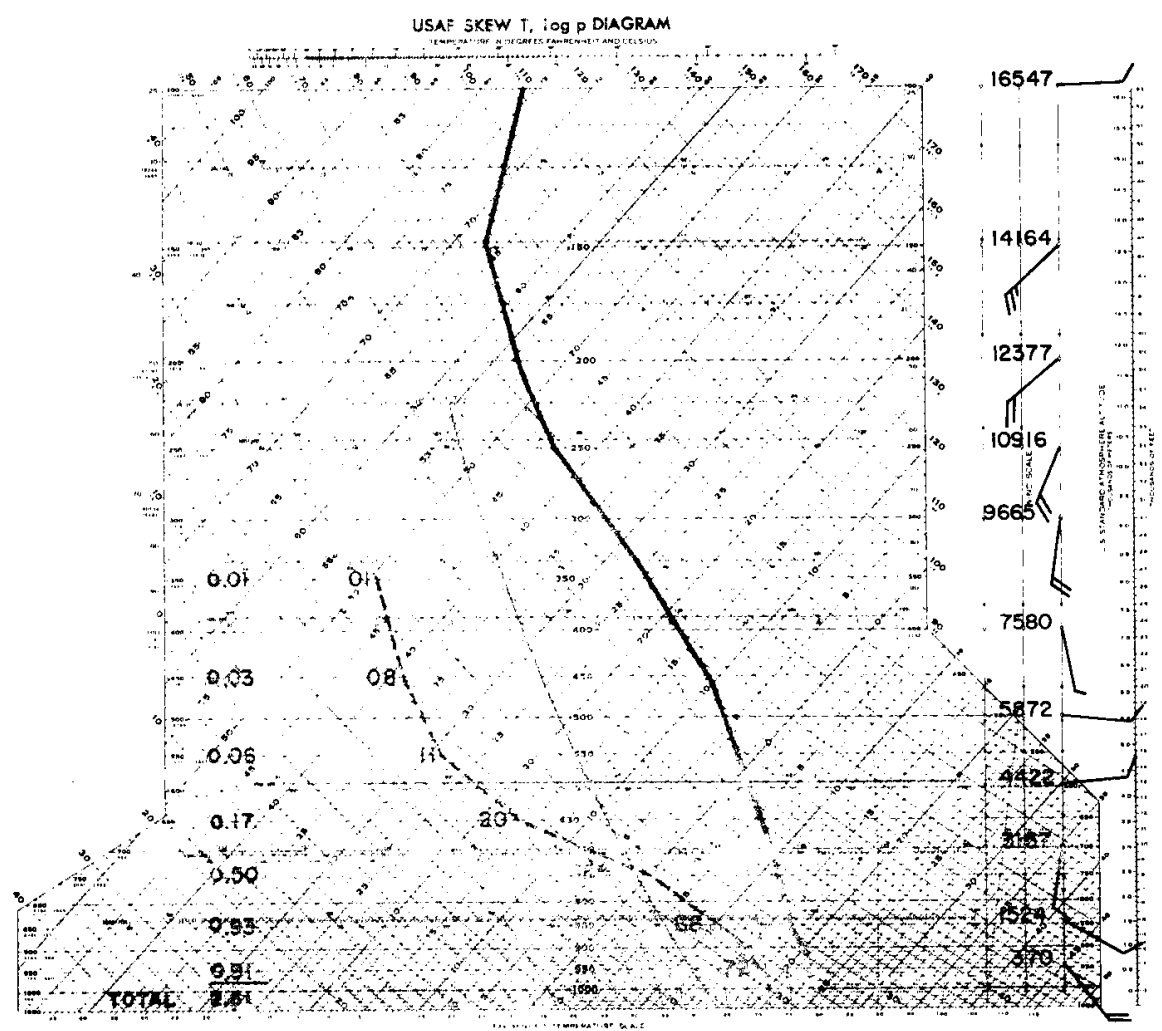

Fig. 10h. Same as for Fig. 10a except Eor the seven driest days during January to April. 
Figure 11 shows the temperature inversions and isothermal layers for this rainy season. It can be observed that the region is largely dominated by a lower middle-level subsidence. In general, the precipitation occurs when the subsidence inversion is not present or is weak. Figure 12 exhibits the relative humidity distribution in the lower troposphere for the same four months. It can again be seen how the rain days exhibit very much higher relative humidity at middle levels. These figures show the general inverse relationship between the strength of the temperature inversion and the relative humidity.

Tables 4 and 5 compare Petrolina's rainiest days relative humidity with the relative humidity of the three days before to three days after the rainest days, the driest days and other tropical weather systems in the Pacific and West Indies. Values are portrayed as percent differences from the seven days average of maximum rainfall. Relative humidity over Petrolina during the rainiest days is very high. Only the West Pacific cloud clusters (see paper by Ruprecht and Gray (1974)) have moisture values as high.

Figure 13 shows the water vapor content or precipitable water in gm $\mathrm{cm}^{-2}$ above Petrolina from January to April. Precipitable water from the surface to $300 \mathrm{mb}$ and $700-300 \mathrm{mb}$ is shown. Note the higher values present during the seven rain episodes. Higure 14 compares the precipitable water for the seven rainy periods with the seven driest periods. Precipitable water variations above $700 \mathrm{mb}$ very well represent the total column vapor differences. Little vapor variations are found at lower levels.

\subsection{Pressure and Winds}

Figure 15 shows the surface pressure departures from the mean for each of the seven rainy periods. It is seen that the surface pressure 


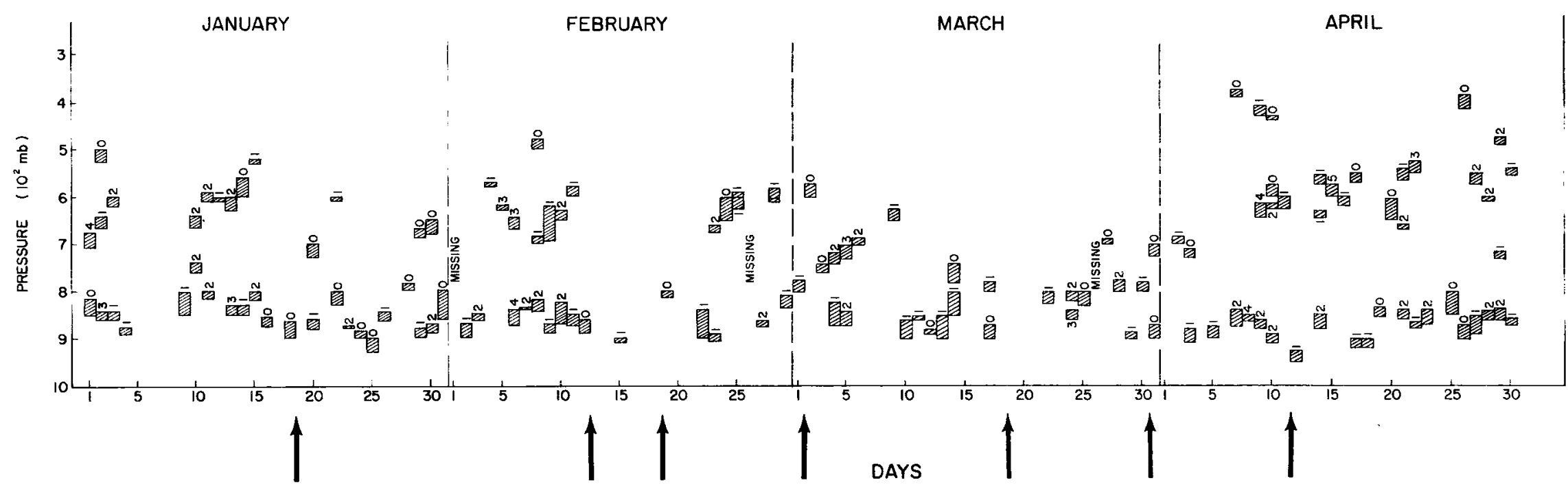

Fig. 11. Height and intensity of inversions or isothermal ( $\frac{\partial T}{\partial Z} \geq 0$ ) layers above Petrolina from January to April 1972. Maximum days of rain during the seven rainy episodes are indicated by arrows. The numbers give the inversion intensity in ${ }^{\circ} \mathrm{C}$. 


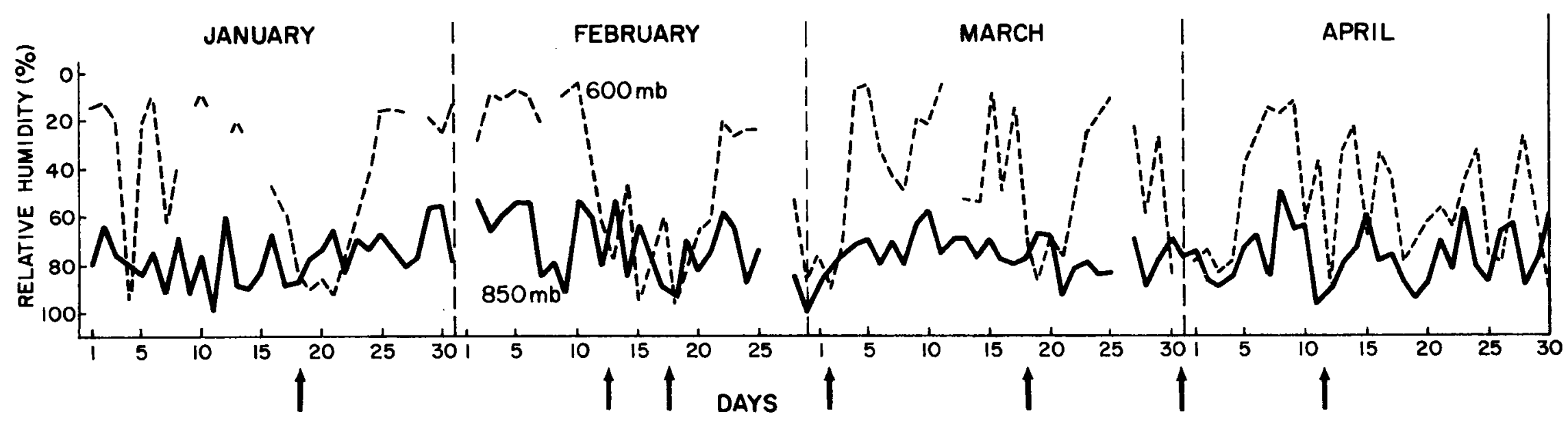

Fig. 12. Relative humidity above Petrolina from January to April 1972. $850 \mathrm{mb}$ (solid curve) and $600 \mathrm{mb}$ (dashed curve). Maximum days of rain during the seven rainy episodes are indicated by the arrows. 
Table 4

Relative Humidity Portrayed as Percent Differences from the Averaged Seven Maximum Rainfall Days During the Rainy Season in Petrolina (January to April 1972)

122

\begin{tabular}{|c|c|c|c|c|c|c|c|c|}
\hline $\begin{array}{c}\text { Pressure } \\
\text { (mb) }\end{array}$ & $\begin{array}{c}\text { Three Days } \\
\text { Before }\end{array}$ & $\begin{array}{c}\text { Two Days } \\
\text { Before }\end{array}$ & $\begin{array}{l}\text { One Day } \\
\text { Before }\end{array}$ & $\begin{array}{l}\text { Rainiest } \\
\text { Days }\end{array}$ & $\begin{array}{l}\text { One Day } \\
\text { After }\end{array}$ & $\begin{array}{l}\text { Two Days } \\
\text { After }\end{array}$ & $\begin{array}{c}\text { Three Days } \\
\text { After }\end{array}$ & $\begin{array}{c}\text { Seven Driest } \\
\text { Days }\end{array}$ \\
\hline Surface & -19 & -21 & -17 & 94 & -9 & -10 & -17 & -26 \\
\hline 950 & -10 & -13 & -4 & 88 & 1 & -2 & -7 & -12 \\
\hline 900 & -6 & -2 & 3 & 81 & 1 & -1 & -2 & -11 \\
\hline 850 & -5 & 3 & 7 & 76 & 1 & -3 & -2 & -8 \\
\hline 800 & -14 & -6 & 1 & 79 & -3 & -6 & -8 & -24 \\
\hline 750 & -20 & -9 & 2 & 79 & -4 & -6 & -11 & -35 \\
\hline 700 & -25 & -16 & -6 & 79 & -9 & -14 & -20 & -49 \\
\hline 650 & -37 & -28 & -21 & 83 & -22 & -26 & -33 & -66 \\
\hline 600 & -48 & -41 & -34 & 83 & -16 & -30 & -36 & -68 \\
\hline 550 & -56 & -52 & -35 & 82 & -12 & -38 & -41 & -71 \\
\hline 500 & -53 & -53 & -36 & 80 & -12 & -39 & -35 & -71 \\
\hline 450 & -53 & -55 & -39 & 77 & -15 & -38 & -28 & -69 \\
\hline 400 & -52 & -49 & -27 & 73 & -15 & -33 & -27 & -65 \\
\hline
\end{tabular}


Table 5

Comparison of Relative Humidity

Relative Humidity Portrayed as Percent Differences from the Petrolina Averaged Seven Maximum Rainfal1 Days

\begin{tabular}{|c|c|c|c|c|c|c|c|c|c|}
\hline $\begin{array}{c}\text { Pressure } \\
\text { (mb) }\end{array}$ & $\begin{array}{l}\text { Seven } \\
\text { Rainiest } \\
\text { Days } \\
\text { From } \\
\text { Jan to } \\
\text { Apr } 1972\end{array}$ & $\begin{array}{l}(12 Z) \text { PE? } \\
\text { Seven } \\
\text { Driest } \\
\text { Days } \\
\text { From } \\
\text { Jan to } \\
\text { Apr } 1972\end{array}$ & $\begin{array}{l}\text { ROLINA } \\
\text { Rain- } \\
\text { iest } \\
\text { Month } \\
\text { Mar } \\
1972\end{array}$ & $\begin{array}{l}\text { Driest } \\
\text { Month } \\
\text { Sep } \\
1972\end{array}$ & $\begin{array}{l}\text { Jordan } \\
1958 \\
\text { Mean } \\
\text { West } \\
\text { Indies } \\
\text { Summer }\end{array}$ & $\begin{array}{l}\text { FROM RU } \\
\text { West Pacific } \\
\text { (12Z) Cloud } \\
\text { Cluster }\end{array}$ & $\begin{array}{l}\text { PRECHT AND GR } \\
\text { West Indies } \\
\text { (00Z) Cloud } \\
\text { Cluster }\end{array}$ & $\begin{array}{l}\text { AY }(1974) \\
\text { West Pacific } \\
(12 Z) \text { Clear } \\
\text { Areas }\end{array}$ & $\begin{array}{l}\text { West Indies } \\
\text { (00Z) Clear } \\
\text { Areas }\end{array}$ \\
\hline Surface & 94 & -26 & -12 & -26 & -11 & -6 & -8 & -9 & -23 \\
\hline 950 & 88 & -12 & -6 & -19 & -7 & -1 & -4 & -2 & -20 \\
\hline 900 & 81 & -11 & -2 & -12 & -3 & 1 & -4 & 1 & -15 \\
\hline 850 & 76 & -8 & -1 & -5 & -3 & 2 & -5 & 0 & -16 \\
\hline 800 & 79 & -24 & -12 & -18 & -13 & -2 & -16 & -11 & -26 \\
\hline 750 & 79 & -35 & -19 & -27 & -20 & -4 & -22 & -20 & -33 \\
\hline 700 & 79 & -49 & -27 & -37 & -23 & -4 & -25 & -25 & -38 \\
\hline 650 & 83 & -66 & -37 & -48 & -30 & -7 & -31 & -30 & -43 \\
\hline 600 & 83 & -68 & -43 & -56 & -32 & -3 & -34 & -27 & -48 \\
\hline 550 & 82 & -71 & -47 & -58 & -34 & -1 & -36 & -31 & -50 \\
\hline 500 & 80 & -71 & -51 & -62 & -34 & -3 & -39 & -33 & -52 \\
\hline 450 & 77 & -69 & -48 & -61 & -33 & -3 & -39 & -40 & -50 \\
\hline 400 & 73 & -65 & -44 & -58 & -29 & -1 & -38 & -42 & -48 \\
\hline
\end{tabular}




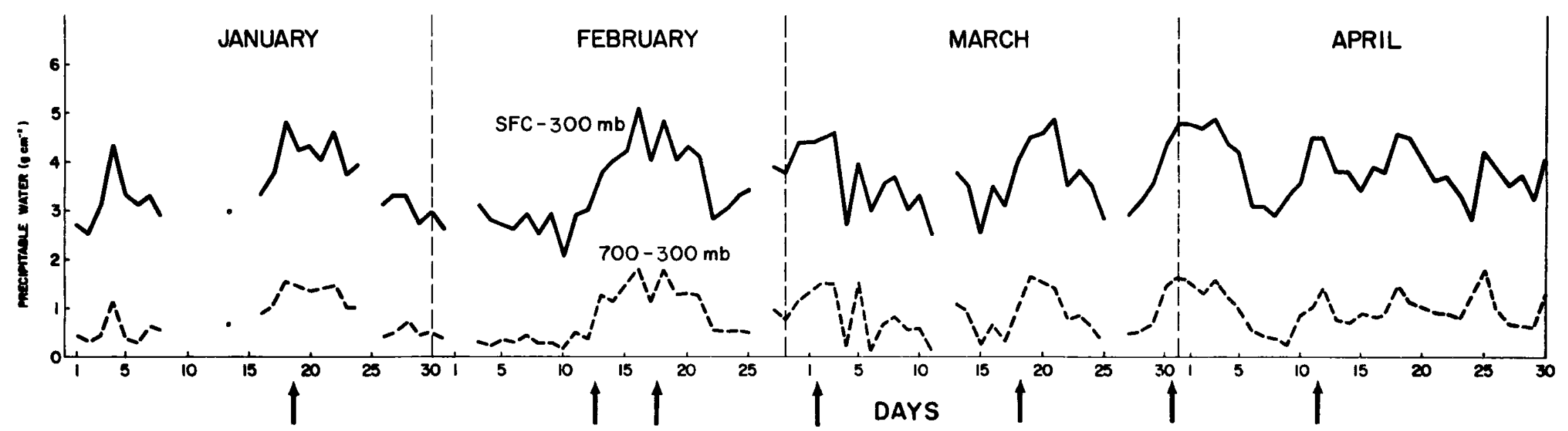

Fig. 13. Precipitable water above Petrolina from January to April 1972. Surface to $300 \mathrm{mb}$ (solid curve) and $700-300 \mathrm{mb}$ (dashed curve). Maximum days of rain during the seven rainy episodes are indicated by arrows. 


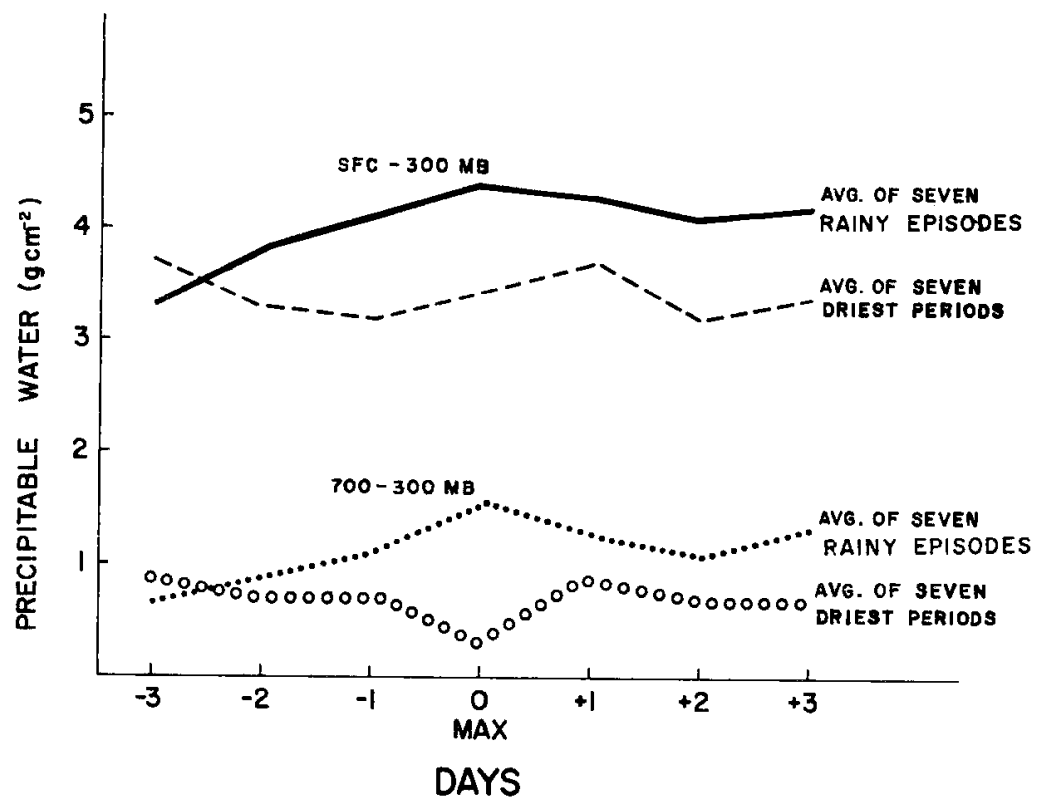

Fig. 14. Averaged precipitable water above Petrolina for the seven rainy and seven driest periods from January to April 1972.

typica1ly falls about $1 \mathrm{mb}$ from 1-2 days before the maximum rain event and then rises 1-2 mb as the rain system progresses through. This indicates an increase of the east to west pressure gradient and a likely strengthening of the east and/or north winds.

Figure 16 shows the geopotential height departures from the monthly mean for the $850,700,600,500,400$ and $300 \mathrm{mb}$ standard pressure levels. It can be seen that the thickness of all layers below $300 \mathrm{mb}$ show a slight decrease on the day before maximum rain. These upper level heights, in general, increase only slightly with the rain. The association of the rain systems with the height gradients is rather weak.

Figure 17 shows a composited data sample of the average wind field relative to the seven traveling precipitation systems. Wind information has been averaged from all the available rawinsonde and pibal stations for seven time periods in each of the seven systems, or 49 total episodes. Data is plotted with respect to the averaged rainfall on these days at 


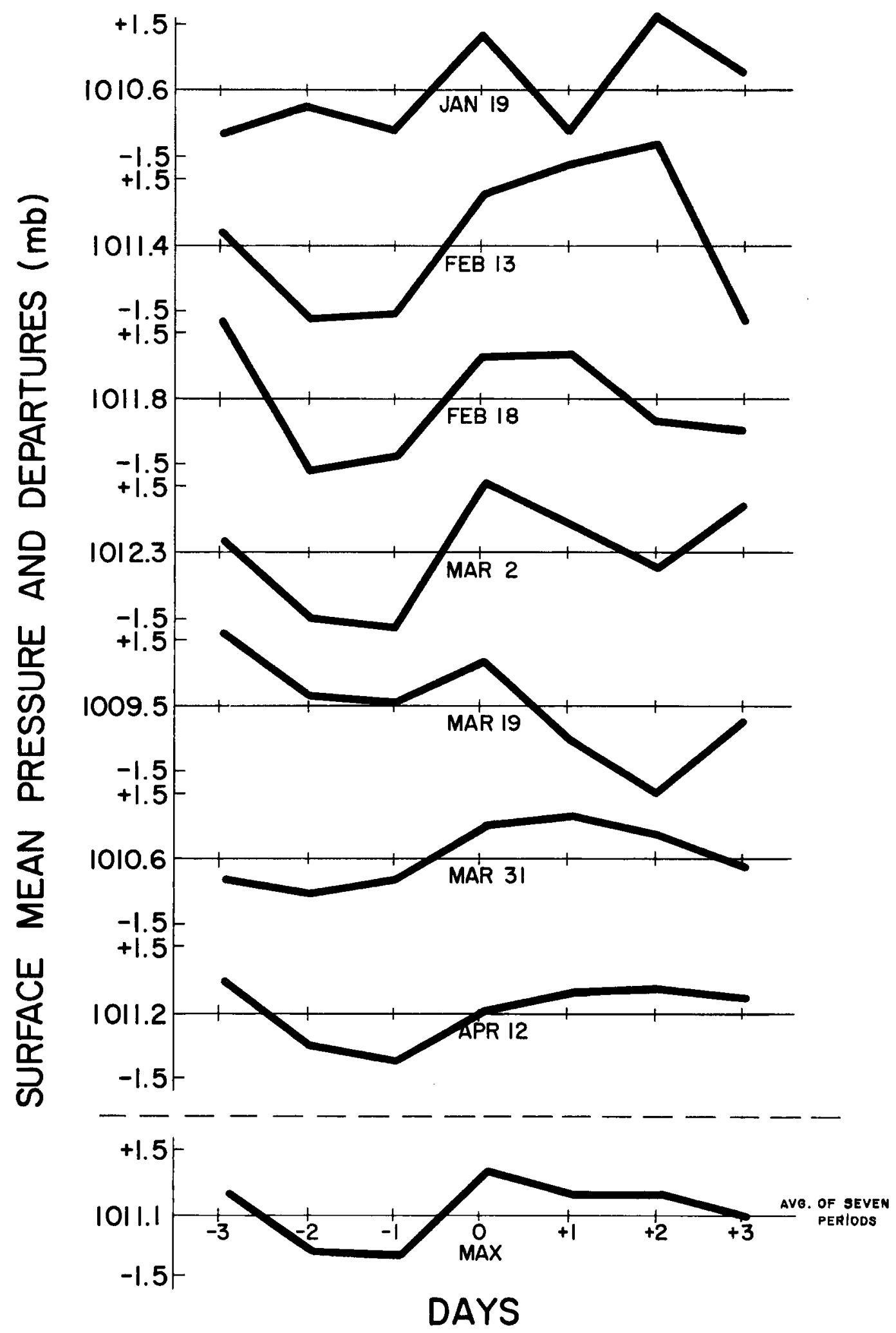

Fig. 15. Surface mean pressure for each one and for the average of the seven rainy periods from January to April 1972 in Petrolina. 

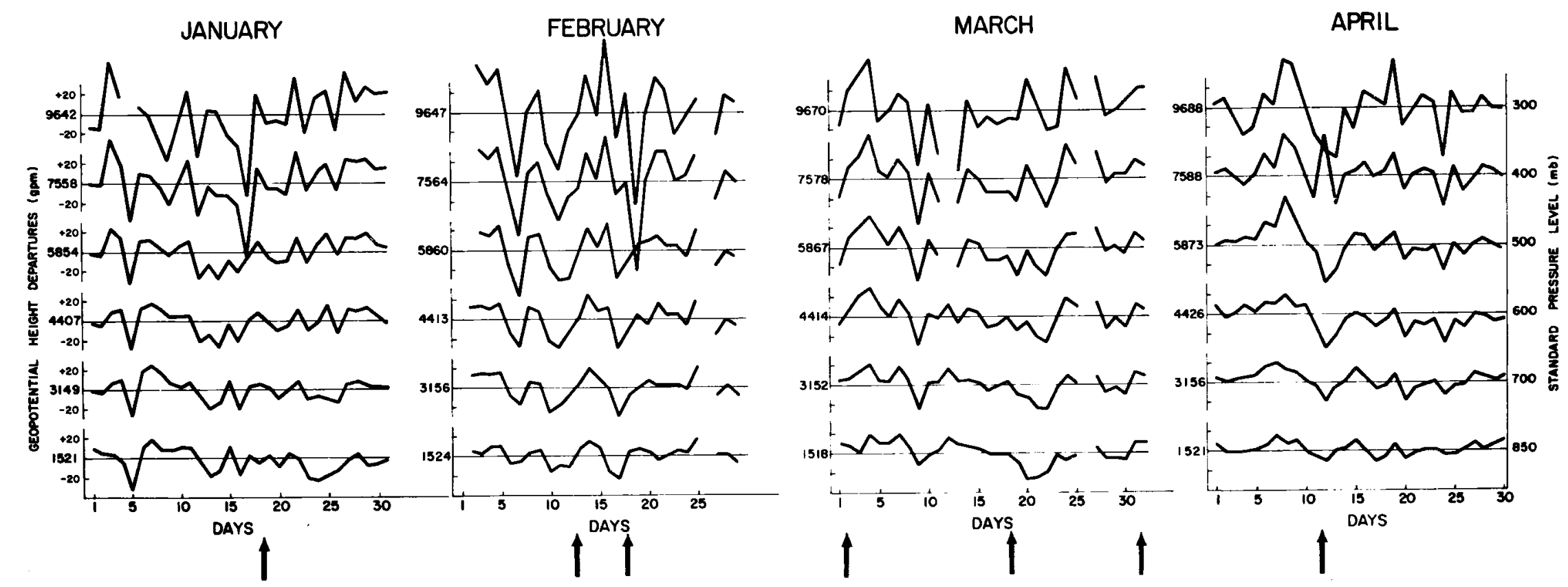

Fig. 16. Standard pressure level geopotential mean monthly height departure above Petrolina from January to April 1972. Maximum days of rain during the seven rainy episodes are indicated by arrows. 
the $600 \mathrm{~m}, 1500 \mathrm{~m}, 700 \mathrm{mb}$ and $200 \mathrm{mb}$ levels. The lower tropospheric flow is from the east. The $200 \mathrm{mb}$ is divergent. Little tropospheric vertical wind shear is present.

Figure 18 shows the resultant gradient level winds for March and September as estimated by Atkinson (1970). These are the wettest and driest months at Petrolina. The horizontal divergence at gradient level

for these two months is found to be $\sim 1.5 \times 10^{-6} \mathrm{sec}^{-1}$ in March and $\sim 3.0 \times 10^{-6} \mathrm{sec}^{-1}$ in September. This indicates that the mean low level subsidence and drying in September is about twice as strong as in March. It also implies that the March rain episodes are a result of a positive deviation of convergence from a mean state which is negative and unfavorable to rainfall genesis.

\subsection{Sate11ite Pictures}

It is important to learn of the broadscale cloud patterns of Northeast Brazil as seen from the satellite. ESSA-8 satellite pictures and ATS-3 movie loops were, however, only available in the late morning and in the middle of the afternoon. It was thus not possible to do a complete satellite study of these weather systems. Nevertheless, some useful information could be gained.

The satellite pictures showed that the rain episode cloud clusters were smaller and less well defined than over the West Pacific and West Indies as discussed by Ruprecht and Gray (1974) and Williams and Gray (1973). They also appeared to be more difficult to track than the cloud clusters in the other regions.

Figures 19a-d show four samples of ATS-3 satellite pictures, two for heavy rain days at Petrolina and two for dry days at Petrolina. 


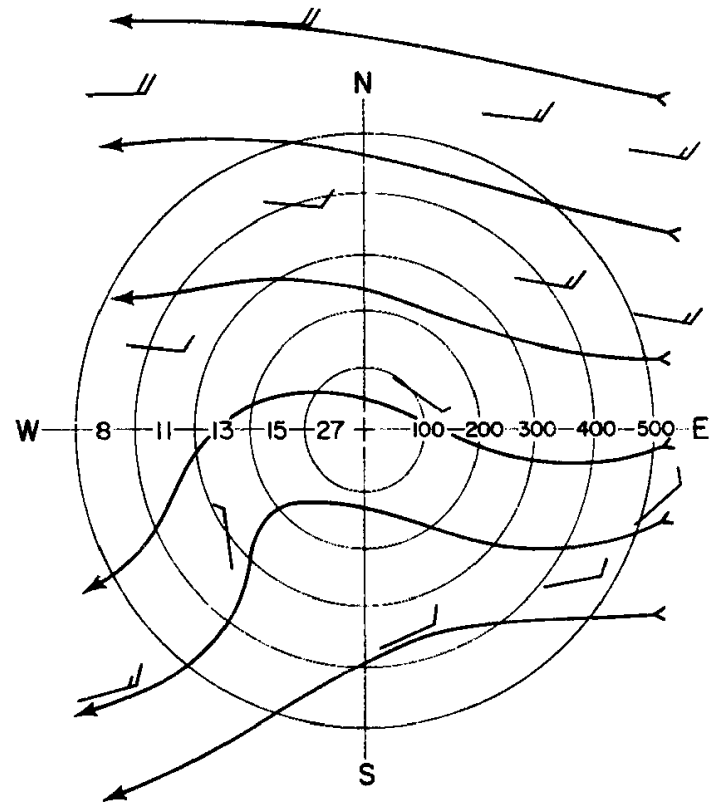

(a) $600 \mathrm{~m}$
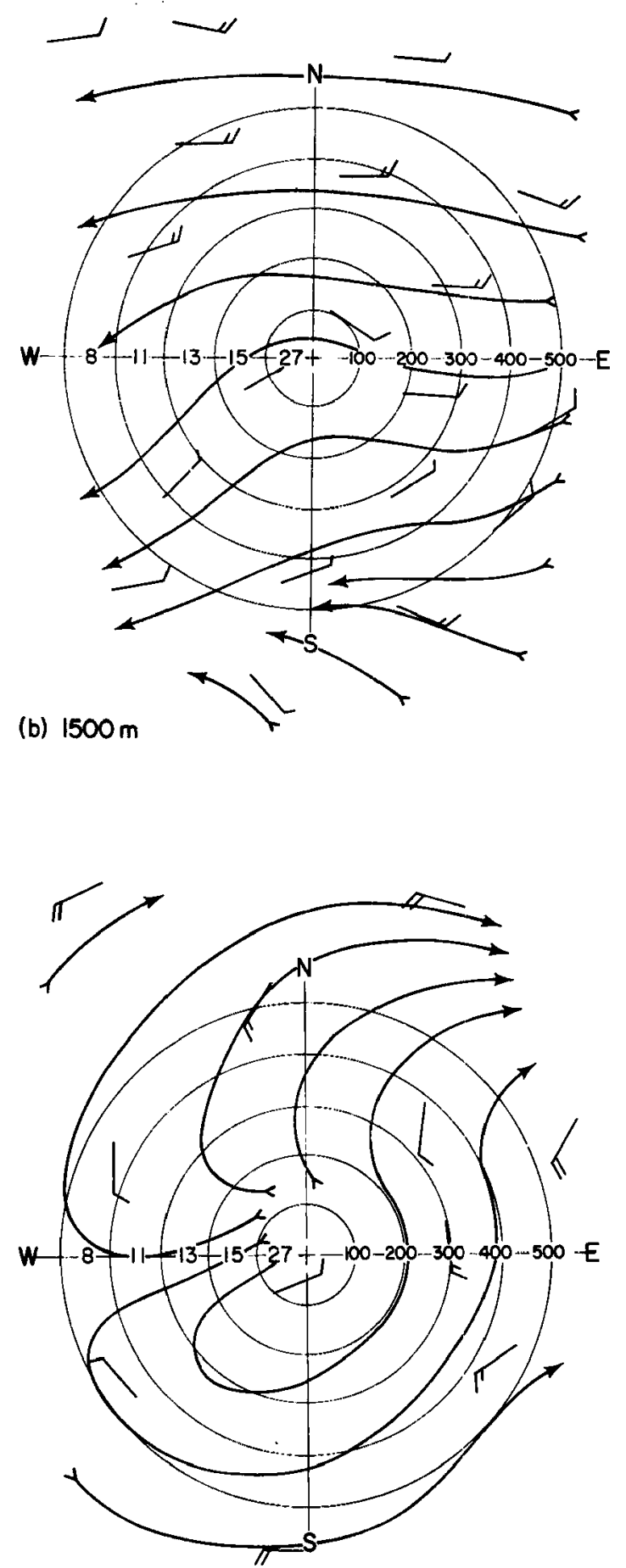

(d) $200 \mathrm{mb}$

Fig. 17. Composited wind field (streamlines) relative to the center of the traveling seven rain systems. On the left side is recorded the mean rainfall in millimeters for each 100 kilometer radial interval. Distance from the rain system center in $\mathrm{km}$ is shown on the right. 

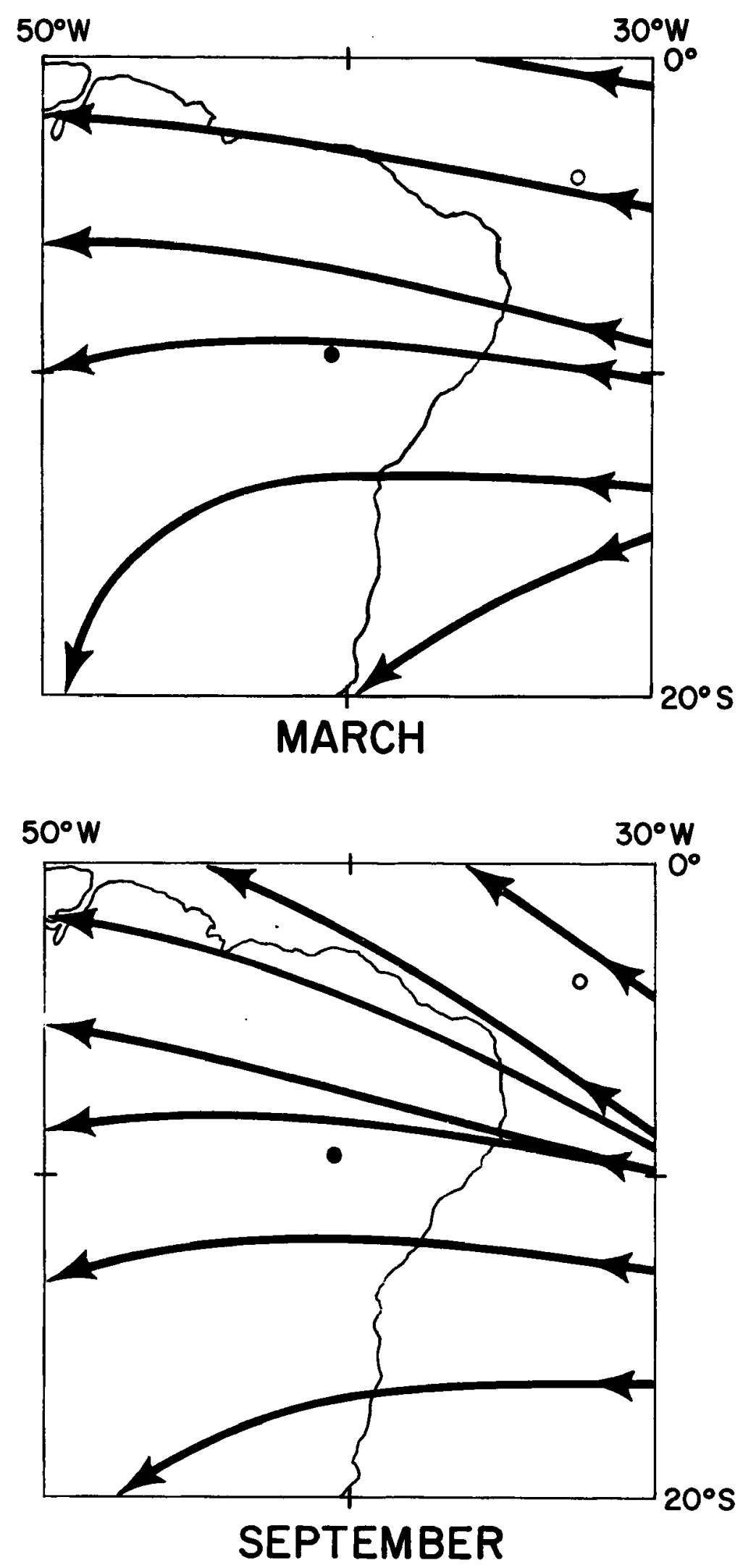

Fig. 18. Resultant monthly gradient level wind as estimated by Atkinson (1970. The black dot shows location of Petrolina. 


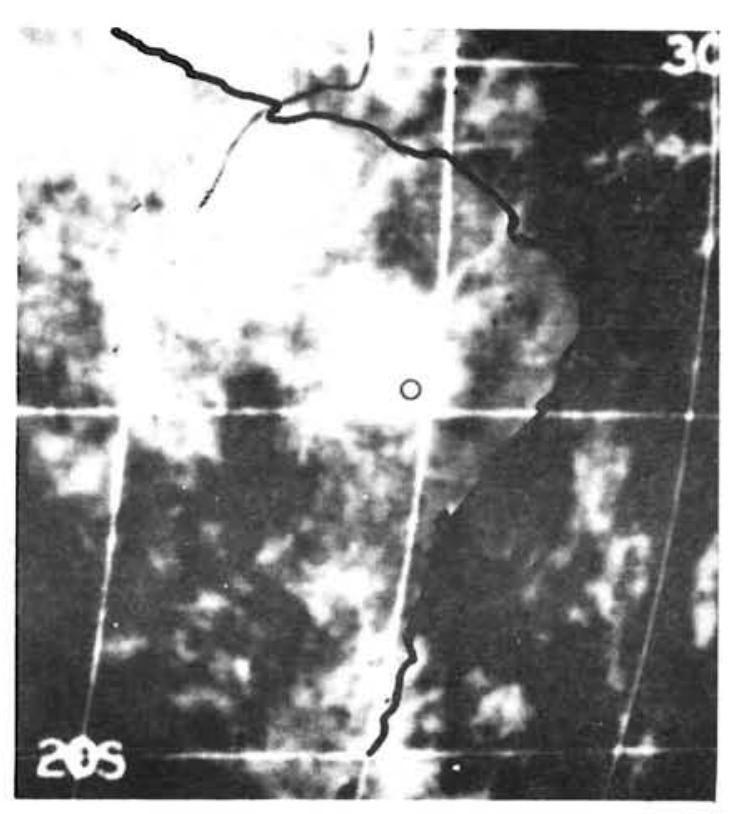

1038 LT

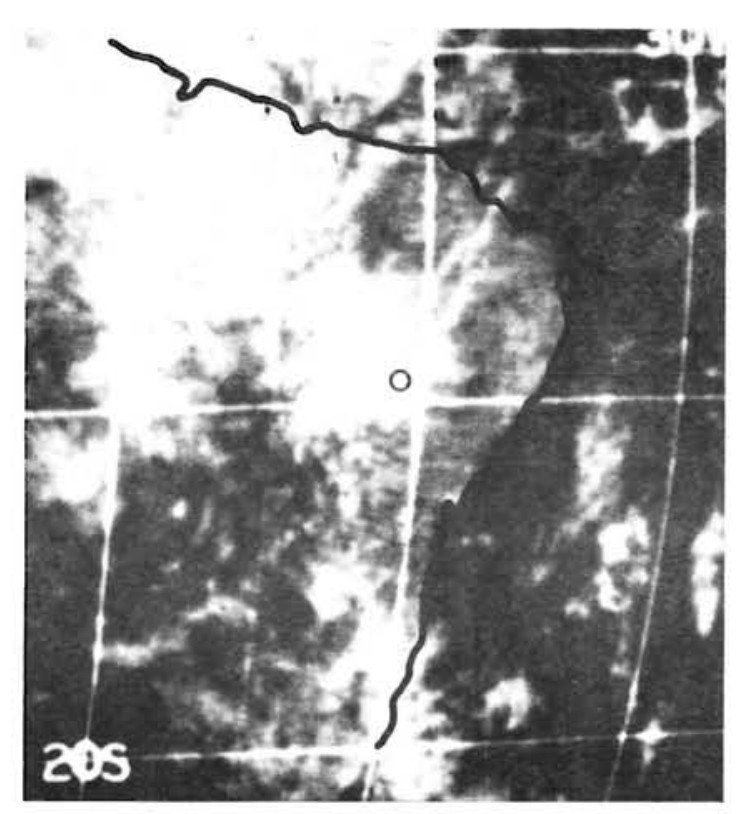

$1159 \mathrm{LT}$

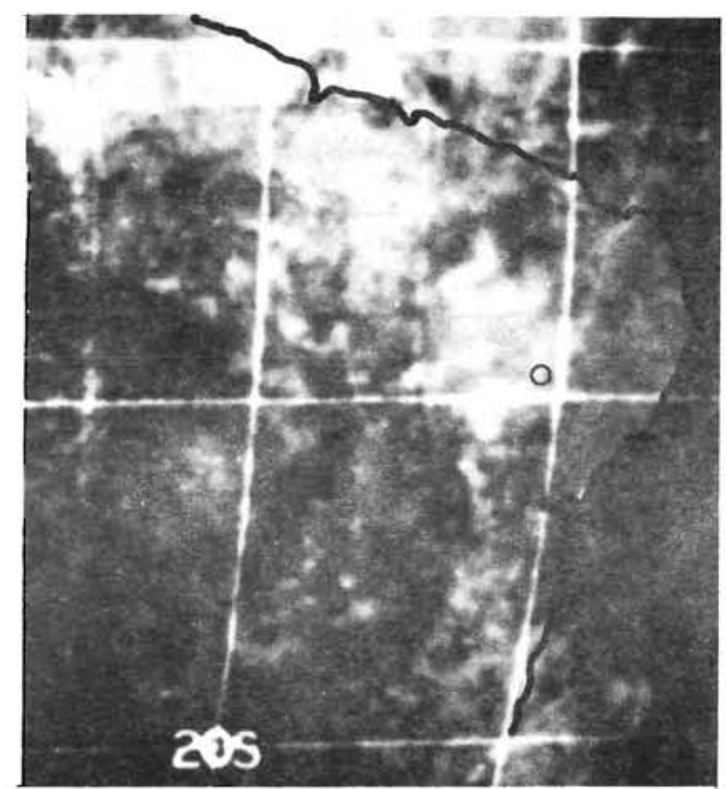

$\omega$

Fig. 19a. Sample of ATS-3 satel1ite pictures for a heavy rain day--12 April 1972 . On this day there was $28 \mathrm{~mm}$ of precipitation between 08-09 Local Time (LT) at Petrolina whose location is shown by the circle. 


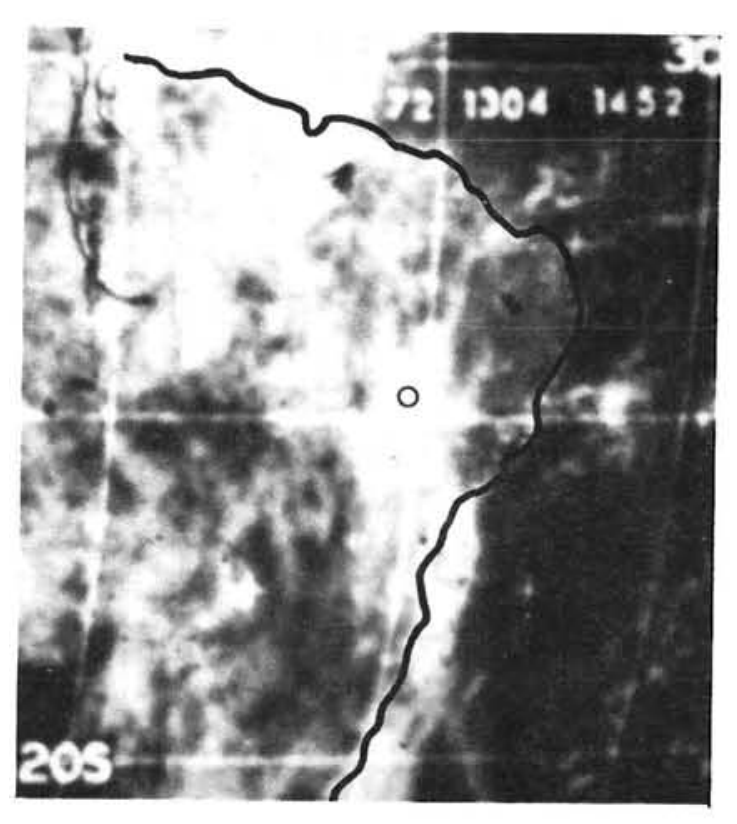

1004 LT

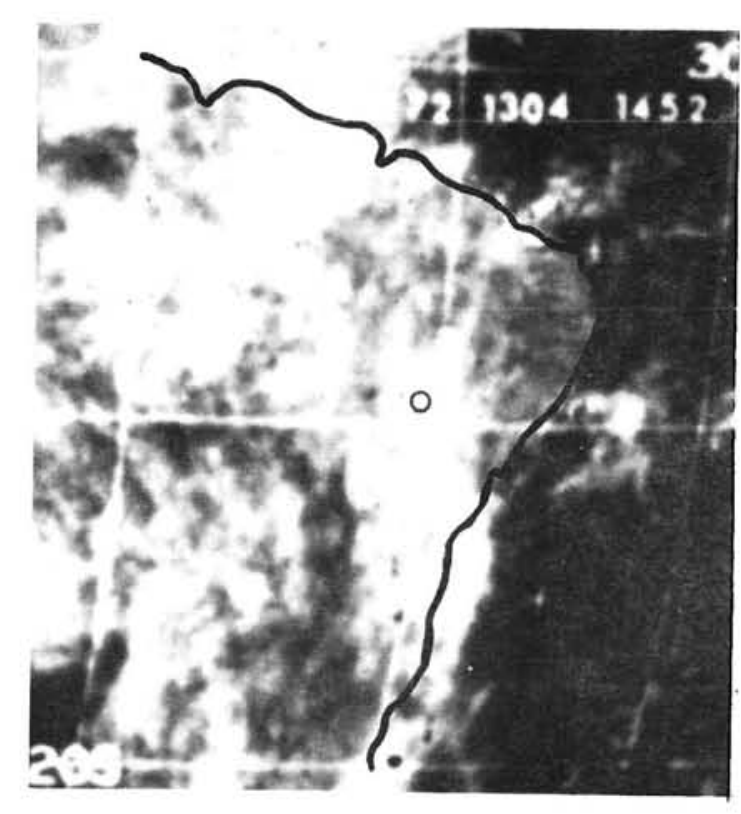

1058 LT

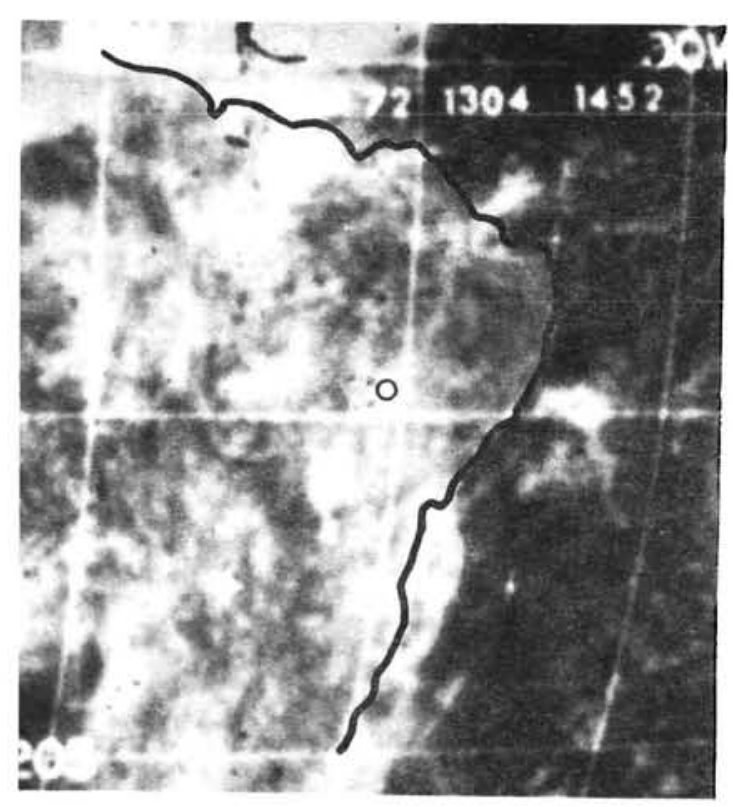

$\underset{\omega}{\omega}$

Fig. 19b. Same as for Fig. 19a except for 01 March 1972. $45 \mathrm{~mm}$ precipitation was measured between 15 LT of the previous day and 10 LT of the day shown, $30 \mathrm{~mm}$ fel1 between 09-10 LT. 


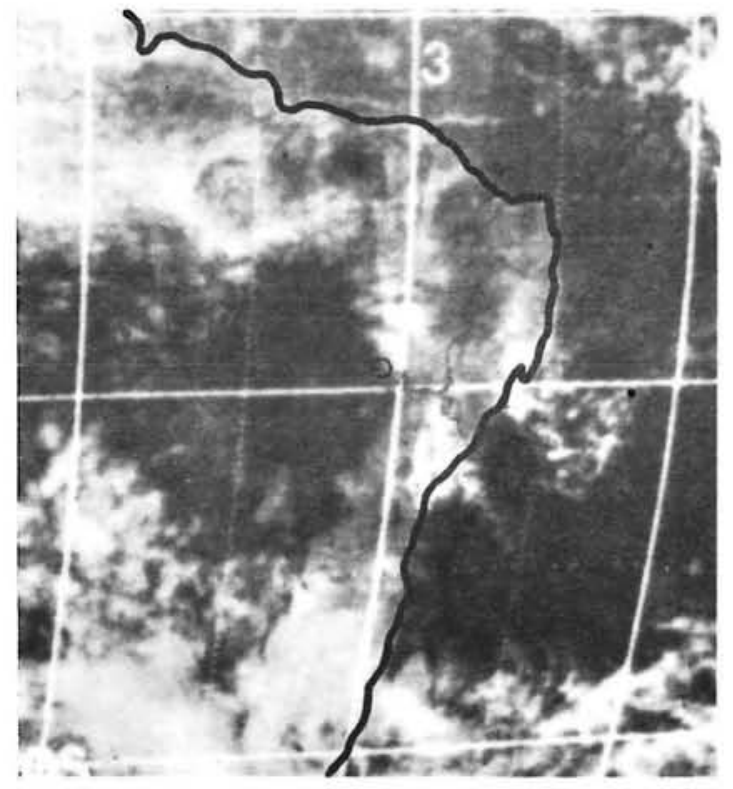

$1000 \mathrm{LT}$

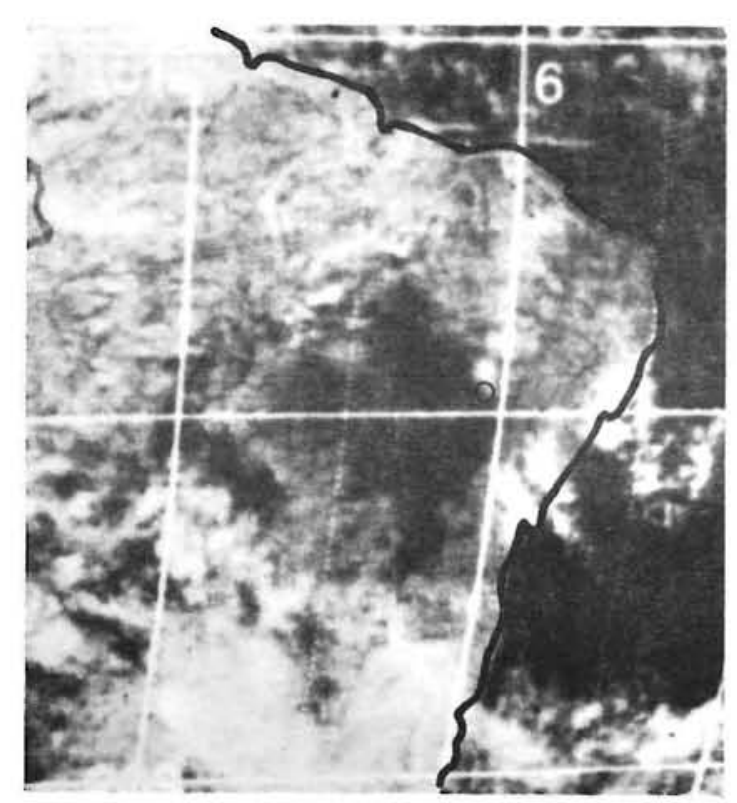

1121 LT

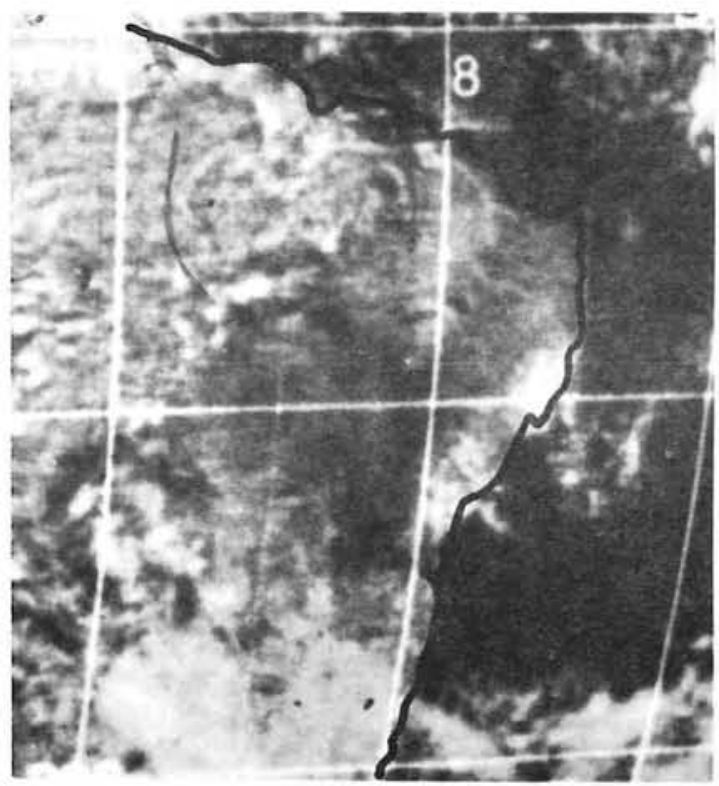

$\underset{\sim}{\omega}$

Fig. 19c. Sample ATS-3 satellite pictures for a dry day--08 April 1972. 


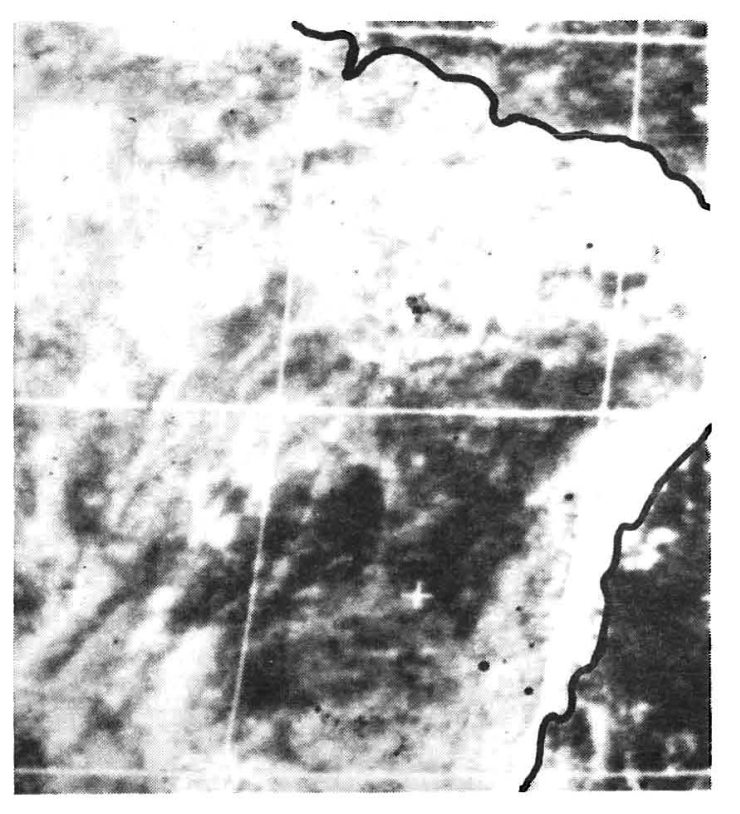

1123 LT

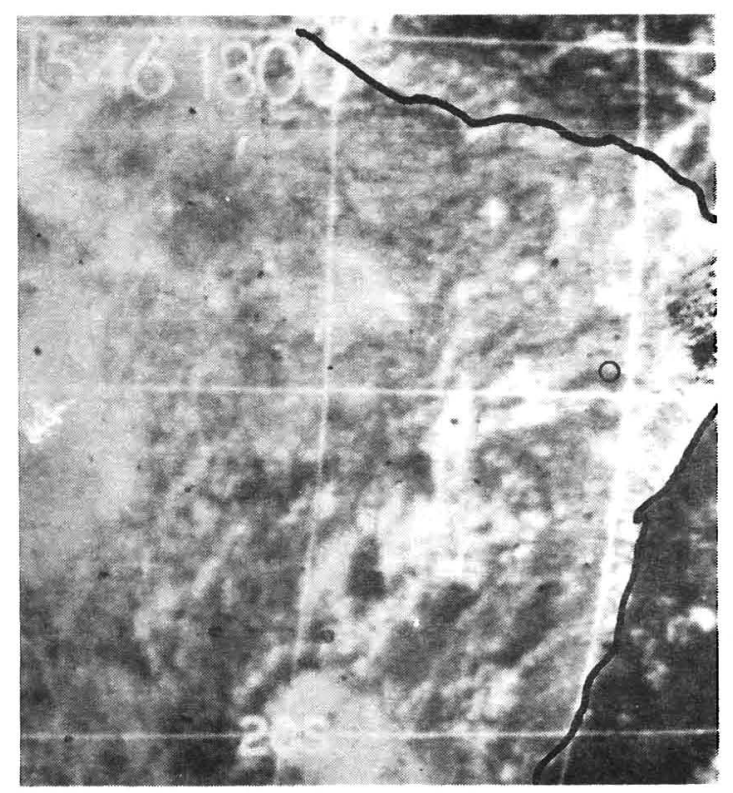

1217 LT

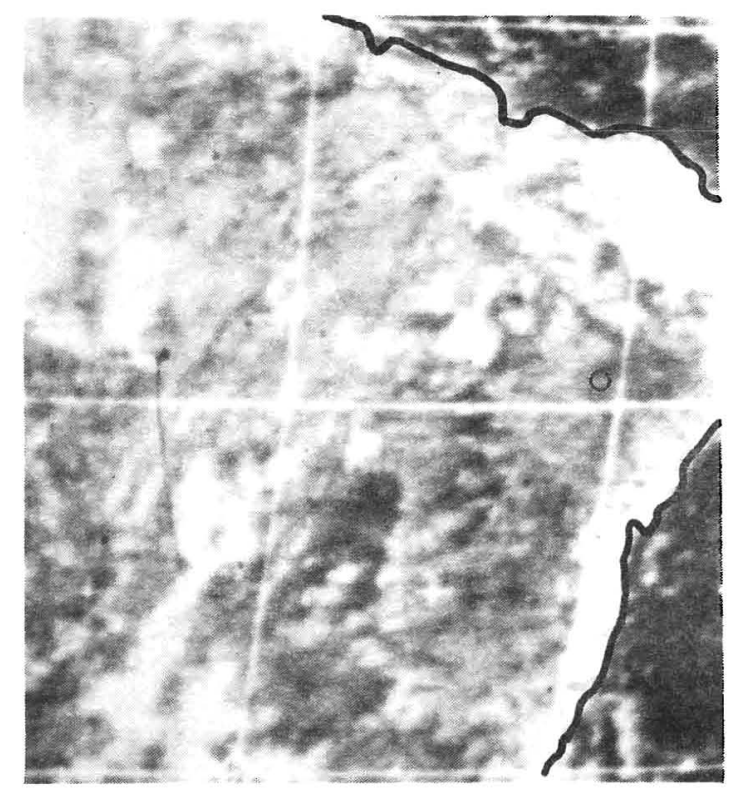

$\underset{\infty}{\infty}$

Fig. 19d. Same as for Fig. 19c except for 07 February 1972. 


\subsection{Cloud Cover}

Figures $20 a-c$ show ESSA- 8 cloud cover (in oktas) averaged by $2^{\circ}$ Marsden squares for all seven rainy episodes in Petrolina from three days before to three days after the day of maximum rain. Also shown are the average of the seven January through April driest days and the difference between the average wettest and average driest days.

From the daytime surface observations and the ESSA-8 satellite pictures, it could be determined that the Petrolina region had an average rainy season cloudiness of between 5 and 8 oktas. Most of the clouds were cumulus and stratocumulus which were organized in small cloud clusters of about $1-2^{\circ}$ diameter. Altocumulus, altostratus and cirrus were often also present but in lesser amounts.

It was not expected that the differences between wet and dry days cloudiness were only 2 to 4 eights. There is typically a lot of middle level layered type clouds and lower stratocumulus cloudiness during the rainy season. The sparsity of rainfall is due not to a lack of cloudiness, but due to the infrequency of $\mathrm{Cb}$ convection.

The ATS-3 movie loop observations indicate similar cloud amounts. Surface measurements of Petrolina cloudiness show that cloud bases of low clouds average $\sim 700 \mathrm{~m}(2300 \mathrm{ft})$, middle clouds $\sim 2400 \mathrm{~m}(8000 \mathrm{ft})$ and high clouds $\sim 11000 \mathrm{~m}(37000 \mathrm{ft})$.

Any conclusions we could draw about the diurnal variations of cloudiness would be biased because the Petrolina station only operates from 05 to $19 \mathrm{LT}$. In this period the average cloud cover does not significantly change. The ESSA-8 satellite pictures and ATS-3 movie loops did not help on this point because all were taken during the daytime. 
Figure 21 shows the mean cloud cover (in oktas) for March and September as estimated by Sadler (1970) for this region. These two months were chosen because March represents the wettest month in Petrolina and September the driest month. Very little satellite cloud cover difference is found between the wettest and the driest months. This, again, apnears to indicate that satellite-observed total cloud amount is only slightly related to cumulonimbi and rain frequency. This is often observed in subsidence regions which have high amounts of low level cloudiness with little or no precipitation. 

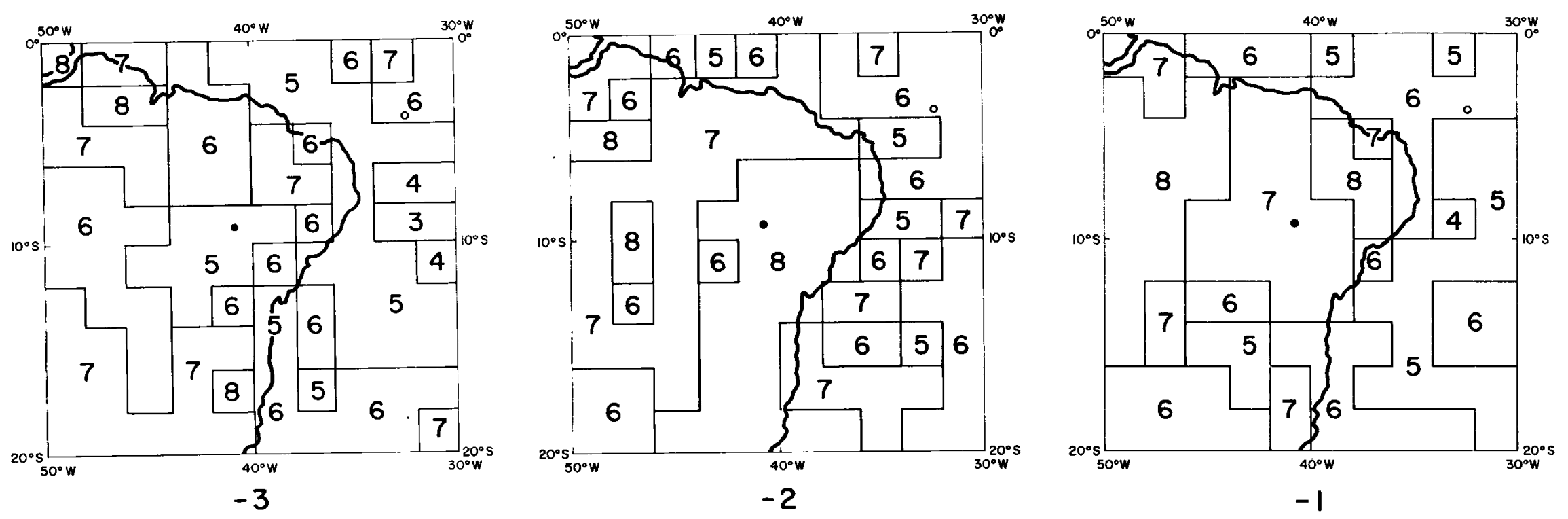

Fig. 20a. ESSA-8 mid-morning average cloud cover (in oktas) by 2 degrees Marsden squares during the seven rainy episodes at Petrolina from three, two and one days before the maximum rain day. (denoted $-3,-2$ and -1 , underneath each diagram. 

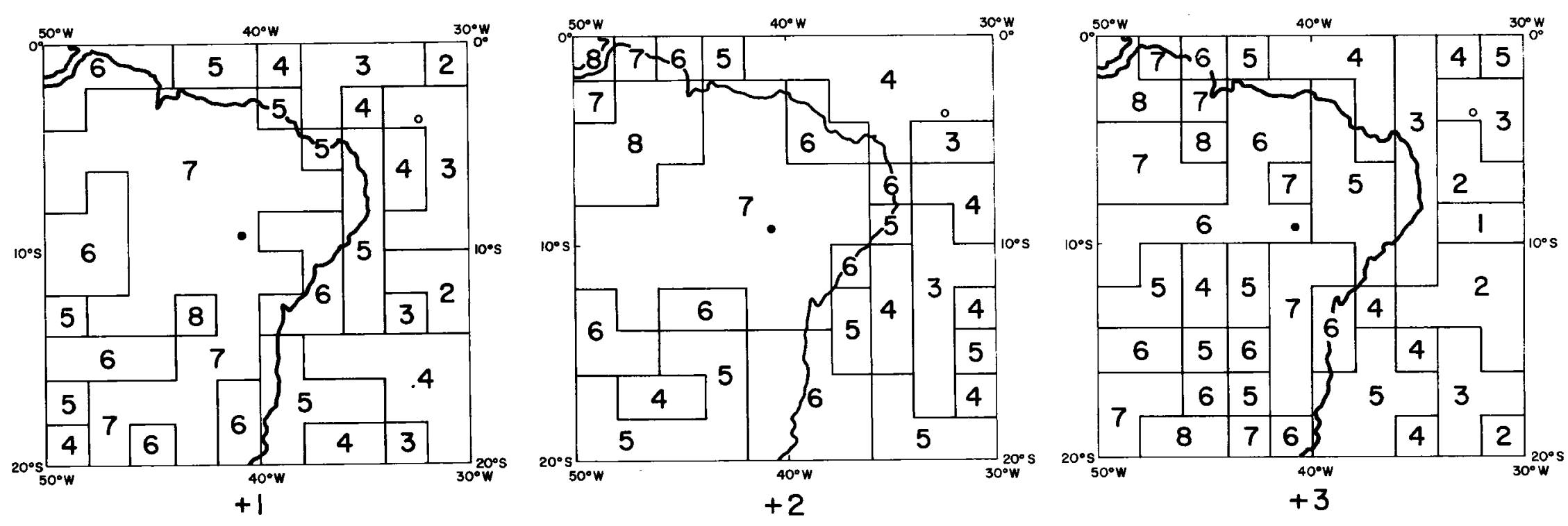

Fig. 20b. Same as for Fig. 20a except for one $(+1)$, two $(+2)$ and three $(+3)$ days after the maximum rain day at Petrolina. 

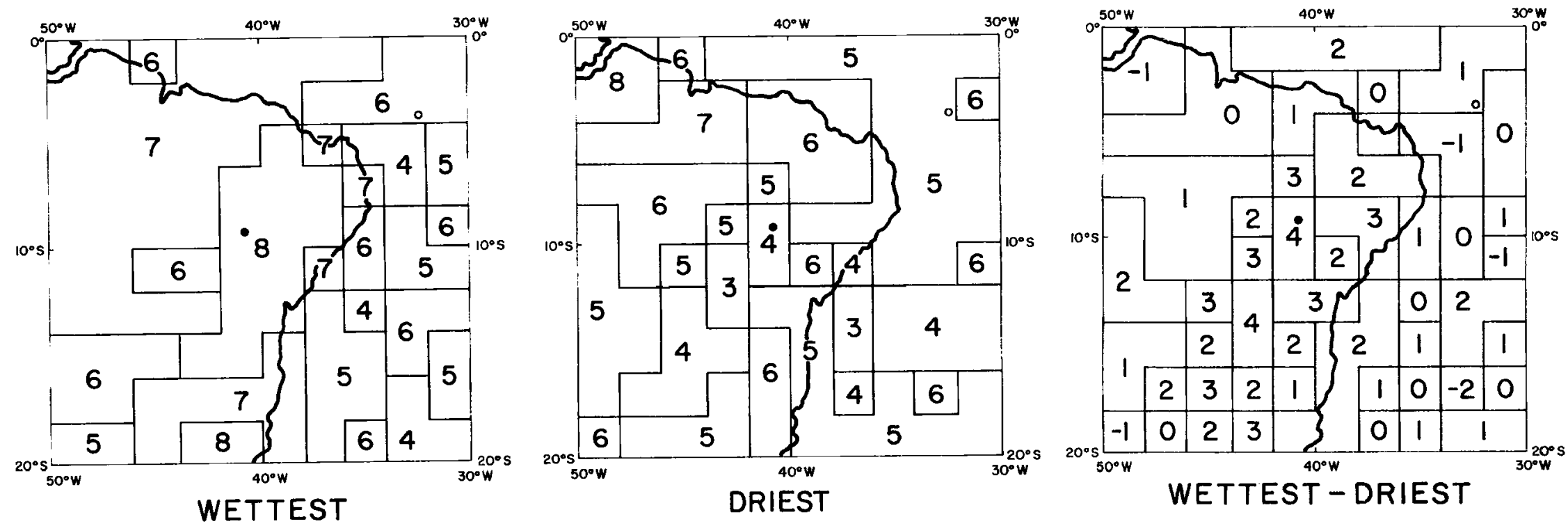

Fig. 20c. Same as for Fig. 20a except for the day of the maximum rain (denoted wettest) shown in the 1eft diagram. The average of the seven driest days from January to April 1972 in Petrolina (denoted driest), and the difference between wettest and driest (denoted wettest-driest) are shown in the center and right diagrams. 

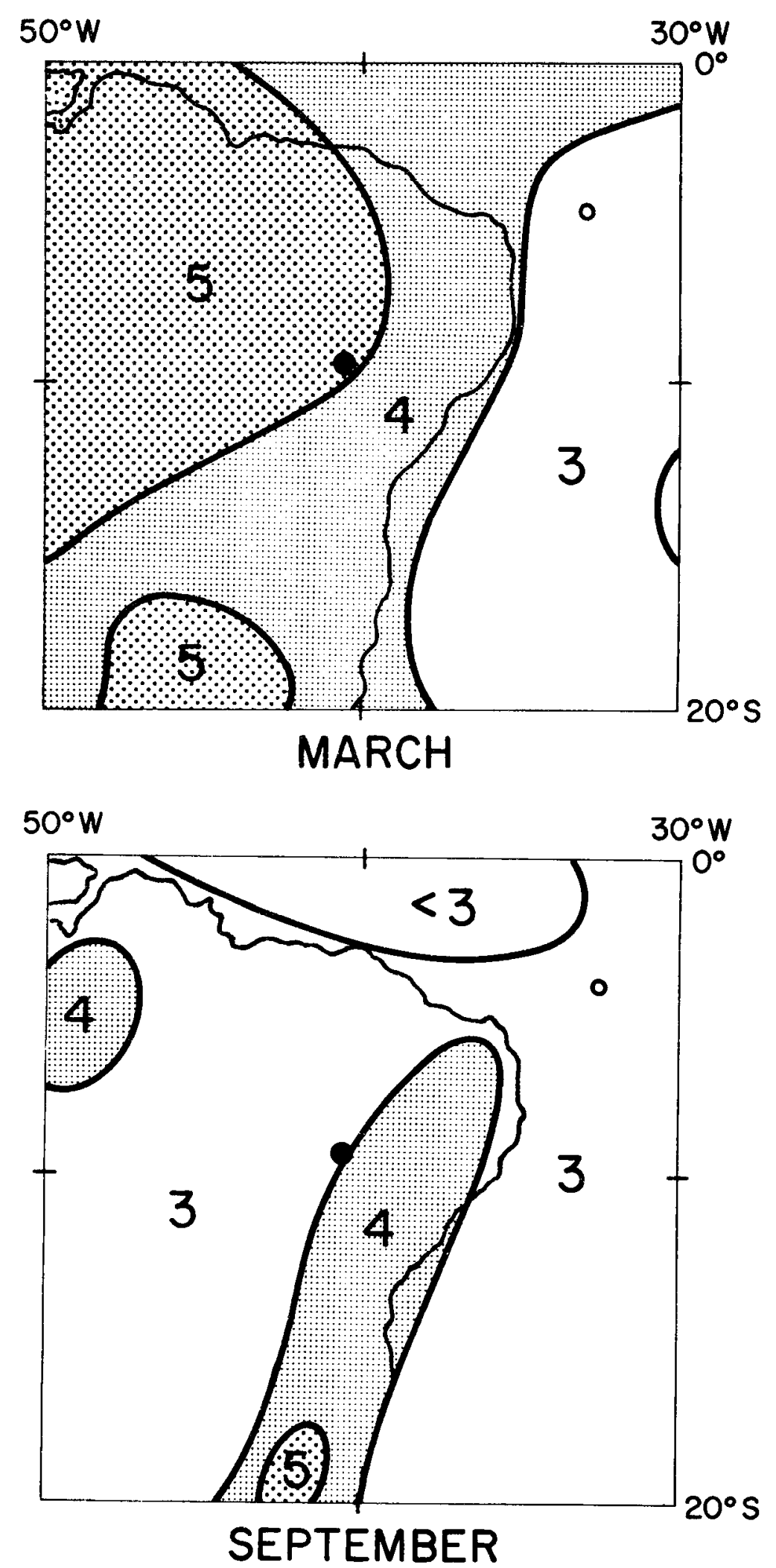

Fig. 21. Mean cloud cover (in oktas) for March (wettest month) and September (driest month) as estimated by Sadler (1970). The black dot shows the location of Petrolina. 


\section{DISCUSSION OF RESULTS}

This chapter attempts to relate the characteristics of the precipitation regimes to the different parameters discussed in the previous chapters.

Northeast Brazil is under a subsidence inversion during most of the rainy season. The causes of this regional subsidence are beyond the scope of this paper. We have only tried to define and describe the inversion. In general, the inversion strength and the precipitation are negatively correlated.

It has been shown that about three-quarters of the total precipitation events in Petrolina occurred in the morning, as opposed to the general case of overland afternoon or early evening rainfall maximum.

Petrolina is located in the São Francisco Valley $\left(9.4^{\circ} \mathrm{S}\right.$ and $\left.40.5^{\circ} \mathrm{W}\right)$. It is surrounded by elevated terrain. During the rainy season the mean wind in the low and middle troposphere is from the east. This flow advects moisture from the Atlantic. During the night and early morning, the radiational cooling of the east slope of the elevated terrain to the west of Petrolina is believed to develop a downslope flow against the mean trade wind current. This is believed to cause an early morning convergence over Petrolina. Middle level moisture is established only when conditions maintaining the trade wind inversion are weakened. It is only at these times that enhanced morning convergence and deep cumulus convection is possible over Petrolina. After sunrise, the elevated east slopes begin to warm. In a few hours the motion due to the elevated terrain reverses itself and upslope motion occurs. This weakens the convergence and decreases the clouds and rain. Elevated terrain rainfall analysis supports this hypothesis. It was found that 
afternoon rainfall occurred at the elevated stations to the west on the same days which showed morning rainfall at the valley stations to the east. Figure 22 shows an idealized and schematic picture of the mean cloud cover and flow distribution over Petrolina and over the elevated terrain to the west during these rain episodes. The strong orographic effects is evident. It is hypothesized that this orographic influence is combined with the influence of the westward propogating cluster system to bring about the necessary low level convergences to generate $\mathrm{Cb}$ convection. Precipitation requires that both influences be present. There is strong evidence for the progression of these weather systems from east to west. Figure 23 shows the day to day variation in the average western boundary of the rainfall systems. The average western bouncary of highest daily rainfall is portrayed from three days before to one day after the occurrence of maximum rainfall at Petrolina. This average was computed taking all rainfall systems in the seven rainy episodes. It appears that the rain occurs in organized systems which move from east to west, in the same direction as the main lower tropospheric flow. Rieh1 (1954) has previously given special emphasis to the fact that the majority of tropical rainfall occurs in organized weather systems.

The wind fields shown in Fig. 17 emphasize that in the low and middle tropospheres the mean flow comes from the east and in the high troposphere it is variable but its average is from the west.

Figure 24 is a more detailed description of the average low level wind field center of the easterly moving rainfall systems. At low levels the wind flow close to the disturbed center is from the west. As the soundings were in the morning, this agrees with our schematic 
47
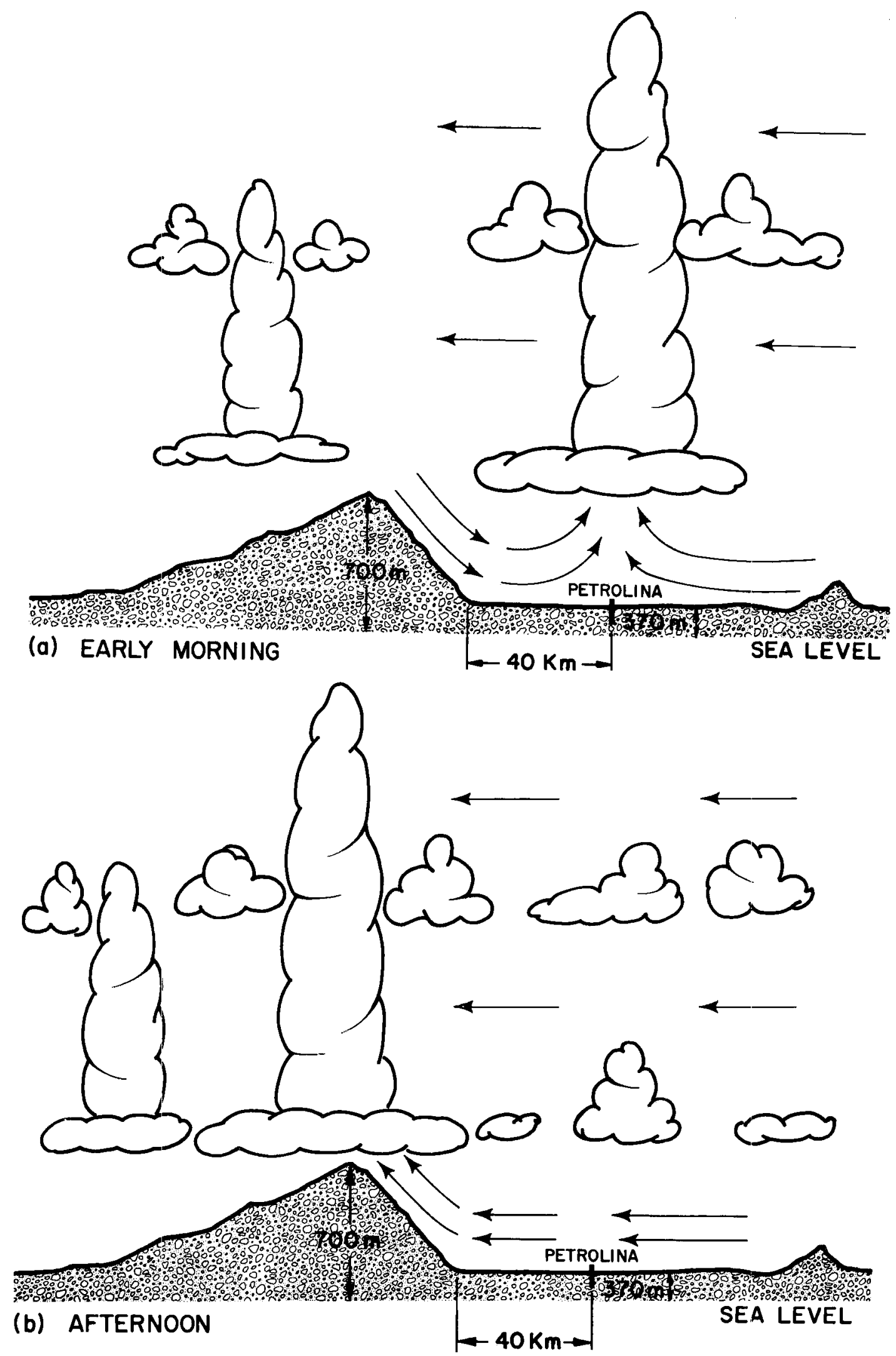

Fig. 22. Schematic picture of the hypothesized typical cloud cover and flow distribution over Petrolina and on the elevated terrain to the west during the seven maximum rain day episodes. 


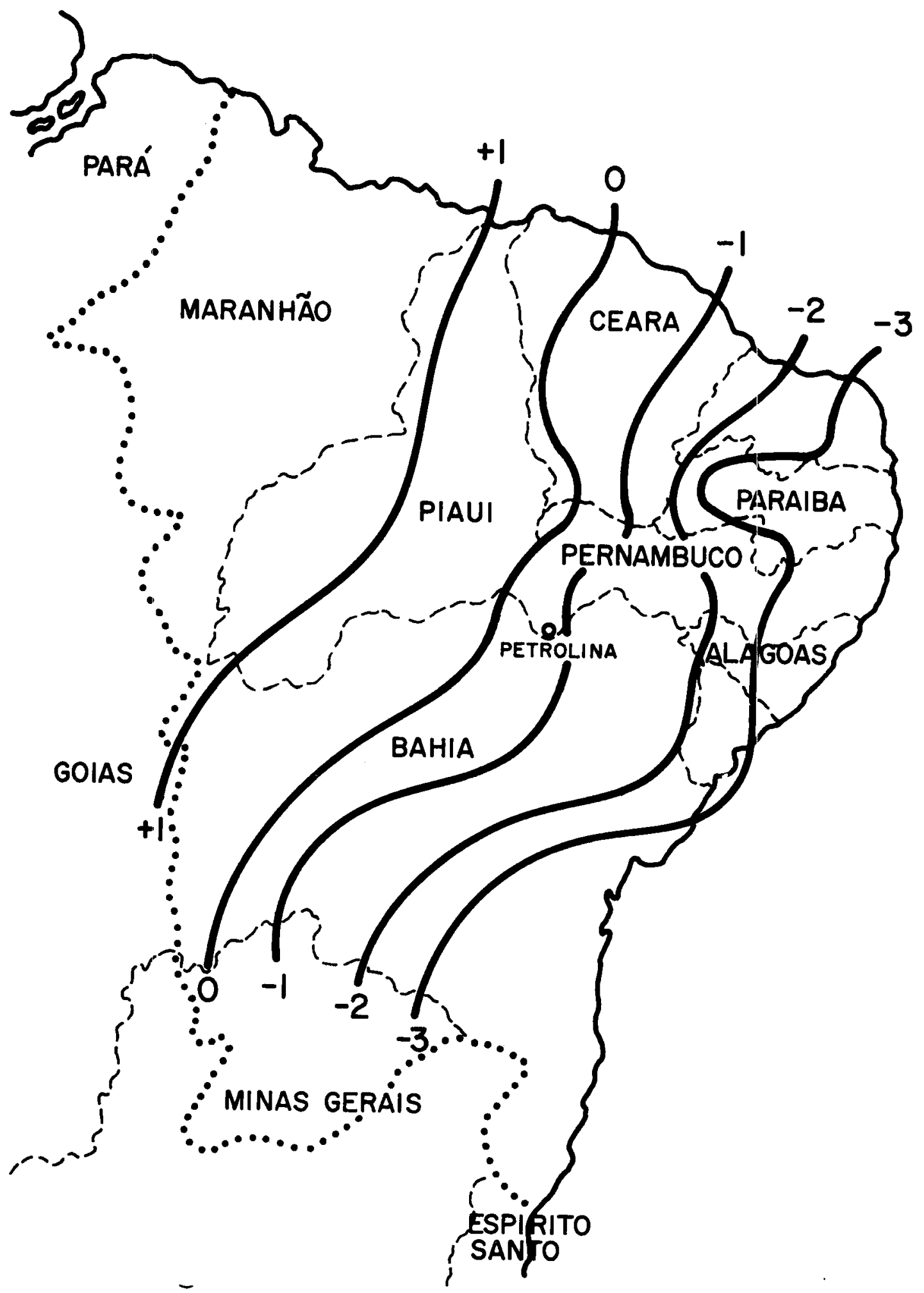

Fig. 23. Average western boundary of the seven rain episodes in Northeast Brazil from three days before (denoted -3) the maximum rainfall day (denoted 0 ) to one day after (denoted +1 ) in Petrolina. This shows how the western edge of the weather systems generally move from east to west. 


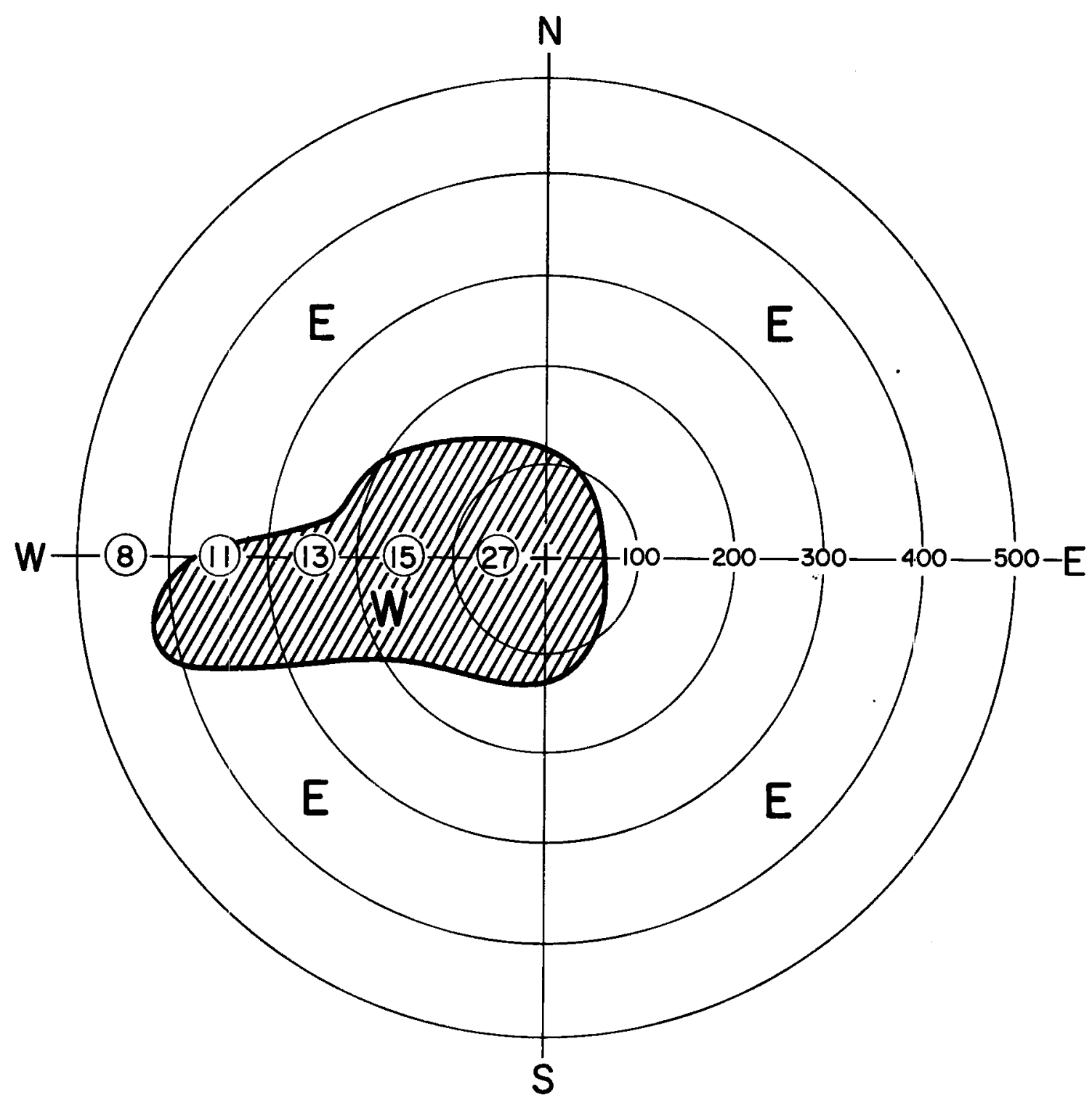

Fig. 24. Mean wind field in the lowest troposphere ( $\mathrm{sfc}$ to $1500 \mathrm{~m}$ ) over the average rainfall system above Petrolina for the seven rain periods. Westerly winds (hached area - $W$ ) and Easterly winds (clear area - E). Numbers on longitudinal line through the center are as explained in Fig. 17. 
view of downslope flow in the early morning. The scarcity of data prevented more detailed description of this low level west wind pattern.

The surface pressure patterns of Fig. 15 help support our contention about the influence of the traveling system on convergence over Petrolina. It can be seen that the surface pressure increased on the days of maximum rain. This means an increased east to west pressure gradient during the period of maximum rainfall. This is likely to manifest itself in an increased wind pattern and enhanced convergence. This is also supported by Fig. 16 where a negative departure from the averaged standard pressure leve1 geopotential heights can be observed 1-2 days before maximum precipitation. This might have some prognostic value.

Figure 25 shows the normal annual precipitation for the period 1931-1960 for five cities in the Northeast Brazil dry region. It can be seen that the maximum of precipitation has an annual movement from west to east, in the opposite direction to the individual rain systems which move from east to west. 


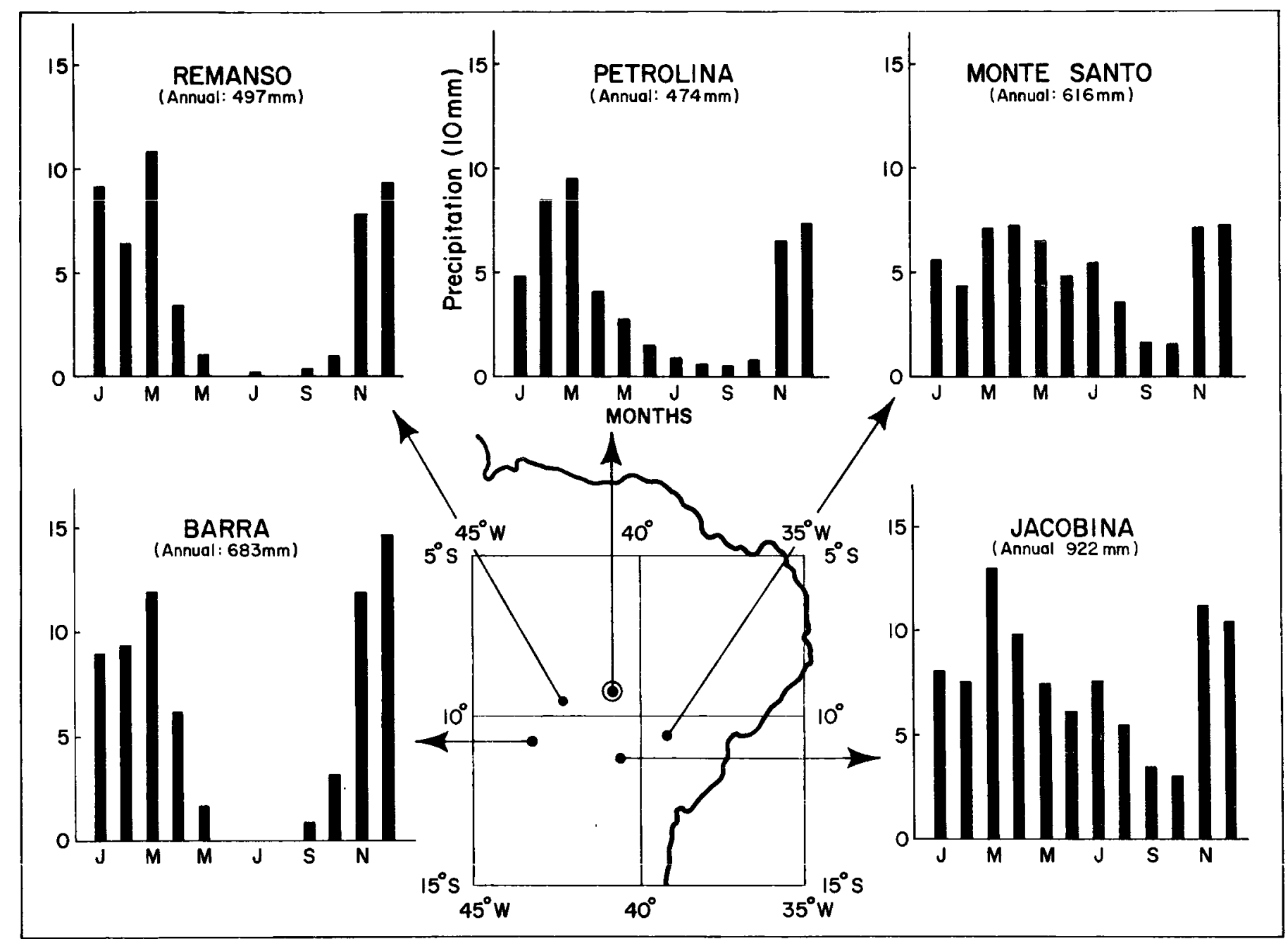

Fig. 25. Norma1 annual precipitation for the period 1931-1960 given in millimeters for five cities in the Northeast Brazil dry region. 


\section{SUMMARY AND CONCLUSIONS}

The rainfall distribution over the Petrolina region during the rainy season from January to April 1972 has been studied. The following conclusions emerge:

1) Most of rainfall over Northeast Brazil occurs in organized systems rather than in the form of random local rains.

2) The rainfall systems appear to move from east to west with a mean speed of $\sim 2-3^{\circ}$ longitude per day. This is considerably slower than the typical tropical disturbance which moves $\sim 6^{\circ}$ longitude per day.

3) Most of the yearly Petrolina rainfall occurs within a few days and within a few hours in the morning. Precipitation over the western elevated terrain, on the other hand, more often occurs in the afternoon.

4) The trade wind inversion appears to play a fundamental role in inhibiting isolated rainfall and keeping the precipitation amounts low. Only well organized weather systems are able to weaken this inversion enough to permit deep cumulus convection.

5) Orographic effects appear to be responsible for the morning rainfall maximum over Petrolina and for the afternoon rainfall over the western elevated terrain. This is believed to be due to radiational cooling of the windward east slopes of the hills during the night that generates downslope motion against the main easterly flow and convergence. By the afternoon Eastern hills slopes are warmed. This causes upslope motion with convergence over the hills (or elevated terrain) and divergence over Petrolina.

6) The moisture source for the rain systems is the Atlantic to the east. Rainfall does not occur unless the relative humidity of the middle layers is 2-3 times above normal.

7) The mean flow in the low and middle troposphere is weakly from the east. At upper levels it is weakly from the west. These rain systems leave little vertical shear with them. Squall line activity would not be an expected mode of convection.

8) This region has a high amount of cloudiness in comparison with its precipitation. Most of this is layered and small cumulus. Even in September, when no rain falls, cloud amounts as determined by the satellites are as high as fifty percent. 
It is important that more research be accomplished on the meteorological conditions of Northeast Brazil. This knowledge may be useful in determining the feasibility of weather modification. 


\section{ACKNOWLEDGMENTS}

The author wishes to express his appreciation to Professor William M. Gray who proposed this research topic and under whose guidance this investigation was performed. Professors Elmar R. Reiter and Everett V. Richardson served on his M.S. committee and offered encouragement.

This research was accomplished while the author was persuing graduate studies in Atmospheric Science at Colorado State University under a scholarship of the "Fundação de Amparo à Pesquisa do Estado de São Paulo-Brasil."

The author is grateful to the Meteorological Service of the Brazilian Air Force, National Weather Service and to SUDENE of Brazil for providing the data for this research. Major Douglas M.D. Strang, Head of the Division of Meteorology of the IAE-CTA of FAB, and his staff also assisted in the Brazilian data collection. The National Environmental Satellite Service (NESS) provided the ATS-3 movie loops. This research was partially supported by the National Science Foundation grants GA-32589X2 and GA-29147.

The author also appreciates assistance in manuscript preparation from Mrs. Barbara Brumit, Miss Cynthia Mathews, Mrs. Felicia Mokler, Mrs. Becky Williamson, and Mrs. Susan Yanish. 


\section{REFERENCES}

Aldaz, L., 1971: Caracterização parcial do regime de chuvas do Brasil. Technical note No. 4. Rio de Janeiro, Brasil, 108 p.

Atkinson, G.D., 1971: Forecaster's guide to tropical meteorology. Air Weather Service (MAC)--WSAF, Technical Report 240, Apri1, 311 p.

Brophy, R.G. and H.0. Piva, 1971: International conference on weather modification. Canberra, Australia. September 11, 1971, pp 145-148.

Courad, V. and L.W. Pellak, 1950: Methods in climatology. Cambridge, Harvard University Press, 459 p.

Departamento Nacional de Meteorologia, 1972a: Bibliografiá sobre meteorologia do nordeste. Rio de Janeiro, Brasil. 3] p.

, 1972b: Balanço hídrico do Brasil. Rio de Janeiro, Brasil, $91 \mathrm{p}$.

, 1973: Estações climatológicas principais (CP) do DN MET. Rio de Janeiro, Brasil, $34 \mathrm{p}$.

Departmento Nacional de Obras Contra as Secas, 1965: Mapas pluviométricos do nordeste do Brasil. Rio de Janeiro, Brasil, 13 mapas.

Diretoria de Rotas Aéreas, 1967: Tabelas climatológicas--Vol. I. TMA-DR-105-03, Rio de Janeiro, Brasil, 78 p.

, 1968: Tabelas climatológicas--Vol. II. TMA-DR-105-06, Rio de Janeiro, Brasil, 63 p.

, 1969: Manual de análise do diagrama "SKEW-T, LOG P". MIA-DR-105-07, Rio de Janeiro, Brasil, Julho, 112 p.

Escritorio de Meteorologia (em convênio com a Sudene), 1970: Normais climatológicas (Área do Nordeste do Brasil). Rio de Janeiro, Brasil, $91 \mathrm{p}$.

Gray, W.M., 1973: Cumulus convection and large-scale circulations, Broadscale-and Meso-Scale Interaction. Mon. Wea. Rev., 101, pp. $339-855$.

Gray, W.M., F. Ruprecht and R. Phelps, 1974: Relative humidity in tropical weather systems. (To be published in J. Atmos. Sci.).

Hoschele, K., 1970: Properties of the precipitation of NE Brazil. São José dos Campos, Brasil, 8 p.

Lorenz, E.W., 1967: The nature and theory of the general circulation of the atmosphere. WMO No. 215 TP 115. 
Namias, J., 1972: Influence of northern hemisphere general circulation on drought in northeast Brazil. Tellus XXIV, pp. 336-343.

Rieh1, H., 1954: Tropica1 meteorology. McGraw-Hil1 Book Co., C-3, $381 \mathrm{p}$.

Ruprecht, E. and W.M. Gray, 1974: Analysis of satellite-observed tropical cloud clusters. Atmospheric Science Paper No. 219, Colo. State Univ., Ft. Collins, Colorado, 80521, 91 p.

Serviço De Meteorologia, 1971: Relaçãodos orgãos de exeçução do serviço de meteorologia do ministério da aeronáutica, 2a. edição. TMA-DR-105-04, Rio de Janeiro, Brasil, 25 p.

Smithsonian Meteorological Tables, 1966: Smithsonian Institution, City of Washington, Sixth Revised Edition, 527 p.

Strang, D.M.G., 1972: Climatological analysis of rainfall normals in Northeastern Brazil. Paper No. IAE-M-02/72, Centro Técnico Aeroespacial, São José dos Campos, Brasil, 70 p.

Williams, K.T. and W.M. Gray, 1973: Statistical analysis of satellite observed trade wind cloud clusters in the western North Pacific. Tellus XXV, pp. 313-336. 
Namias, J., 1972: Influence of northern hemisphere general circulation on drought in northeast Brazil. Te1lus XXIV, pp. 336-343.

Riehl, H., 1954: Tropical meteorology. McGraw-Hill Book Co., C-3, $381 \mathrm{p}$.

Ruprecht, E. and W.M. Gray, 1974: Analysis of satellite-observed tropical cloud clusters. Atmospheric Science Paper No. 219, Colo. State Univ., Ft. Collins, Colorado, 80521, 91 p.

Serviço De Metcorologia, 1971: Relação dos orgãos de exeçução do serviço de meteorologia do ministério da aeronáutica, $2 a$. edição. TMA-DR-105-04, Rio de Janeiro, Brasil, 25 p.

Smithsonian Meteorological Tables, 1966: Smithsonian Institution, City of Washington, Sixth Revised Edition, 527 p.

Strang, D.M.G., 1972: Climatological analysis of rainfall normals in Northeastern Brazil. Paper No. IAE-M-02/72, Centro Técnico Aeroespacial, São José dos Campos, Brasil, 70 p.

Williams, K.T. and W.M. Gray, 1973: Statistical analysis of satellite observed trade wind cloud clusters in the western North Pacific. Tellus XXV, pp. 313-336. 


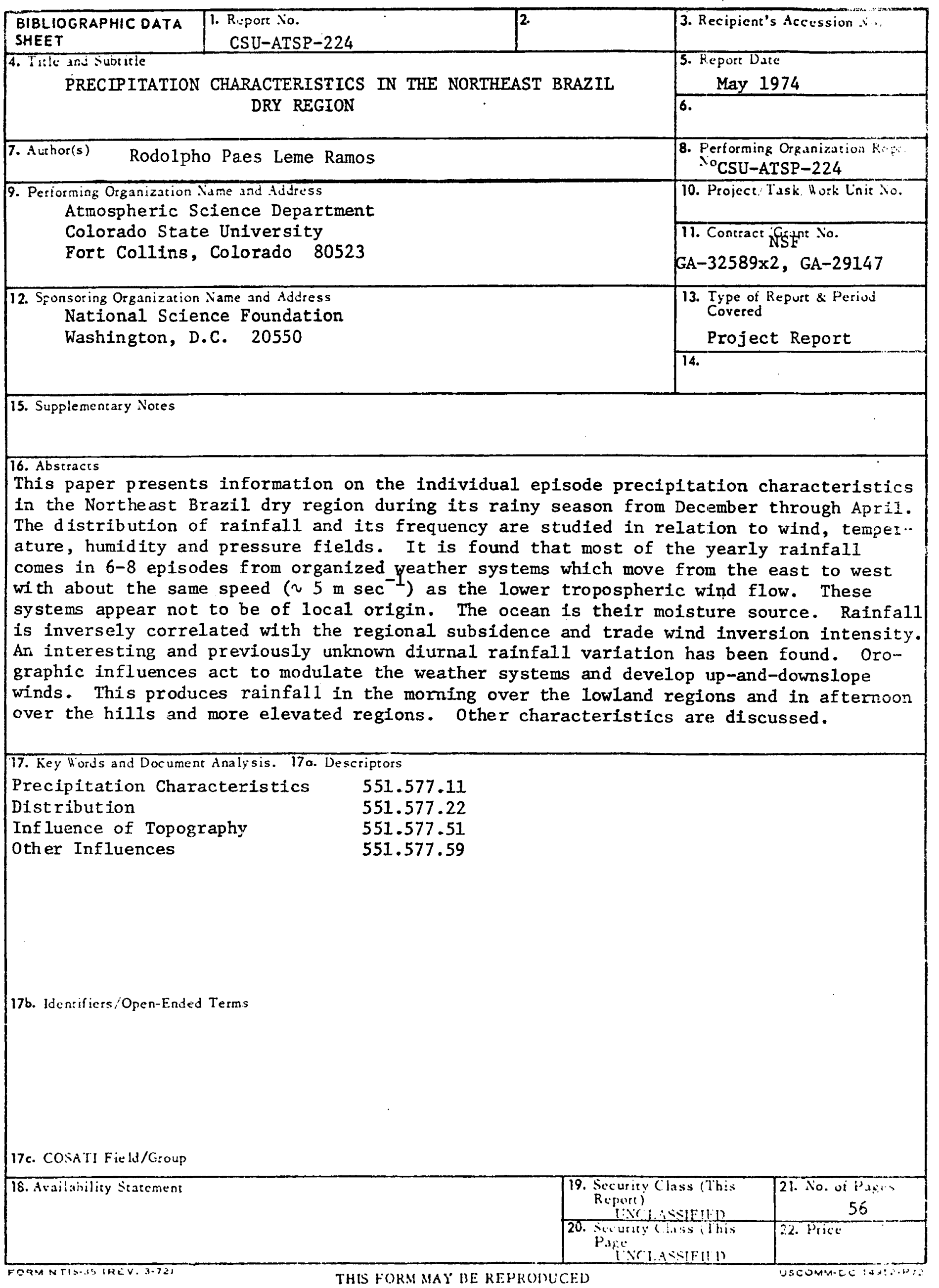

